\title{
The Corruption-Growth Relationship: Does the Political Regime Matter?
}

Link to publication record in Manchester Research Explorer

\section{Citation for published version (APA):}

Saha, S., \& Sen, K. (2020). The Corruption-Growth Relationship: Does the Political Regime Matter? Journal of Institutional Economics.

\section{Published in:}

Journal of Institutional Economics

\section{Citing this paper}

Please note that where the full-text provided on Manchester Research Explorer is the Author Accepted Manuscript or Proof version this may differ from the final Published version. If citing, it is advised that you check and use the publisher's definitive version.

\section{General rights}

Copyright and moral rights for the publications made accessible in the Research Explorer are retained by the authors and/or other copyright owners and it is a condition of accessing publications that users recognise and abide by the legal requirements associated with these rights.

\section{Takedown policy}

If you believe that this document breaches copyright please refer to the University of Manchester's Takedown Procedures [http://man.ac.uk/04Y6Bo] or contact uml.scholarlycommunications@manchester.ac.uk providing relevant details, so we can investigate your claim.

\section{OPEN ACCESS}




\title{
The corruption-growth relationship: does the political regime matter?
}

\author{
Shrabani Saha ${ }^{1 \star \dagger}$ and Kunal Sen ${ }^{2}$ \\ ${ }^{1}$ Lincoln International Business School, University of Lincoln, Lincoln, United Kingdom and ${ }^{2}$ UNU-WIDER, Helsinki, \\ Finland \\ ${ }^{*}$ Corresponding author. Email: ssaha@lincoln.ac.uk
}

(Received 20 November 2019; revised 3 August 2020; accepted 3 August 2020; first published online 12 November 2020)

\begin{abstract}
Corruption is widely believed to have an adverse effect on the economic performance of a country. However, many East-and-Southeast-Asian countries either achieved or currently are achieving impressively rapid economic growth despite widespread corruption - the so-called East-Asian-Paradox. A common feature of these countries was that they were autocracies. We re-examine the corruption-growth relationship, in light of the East-Asian-Paradox. We examine the role of political regimes, in mediating corruption-growth relationship using panel data over 100 countries for the period 1984-2016. We find clear evidence that corruption-growth relationship differs by the type of political regime, and the growth-enhancing effect of corruption is more likely in autocracies than in democracies. The marginal effect analysis shows that in strongly autocratic countries, higher corruption may lead to significantly higher growth, while this is not the case in democracies. Alternatively, democracy is not good for growth if there is a high level of perceived corruption. We provide suggestive evidence that the mechanism by which corruption is growth-enhancing in autocracies is through the perceived credibility of the commitment of ruling political elites to economic freedom, thereby providing confidence to the firms to invest, leading to long-term growth.
\end{abstract}

Key words: Autocracy; corruption; democracy; economic growth; political regimes

JEL Codes: E02; O11; O43

\section{Introduction}

How does corruption affect economic growth? The theoretical literature provides no clear guidance on this issue. One strand of the theoretical literature argues that corruption increases economic growth by enabling investors to avoid bureaucratic delay through the use of 'speed money' and by encouraging lowly paid government employees to work harder if they could supplement their income by levying bribes (De Soto, 1989; Egger and Winner, 2005; Huntington, 1968; Leff 1964; Lui, 1985). Another strand of the theoretical literature contends that corruption has a negative effect on economic growth by reducing investment, both in physical and human capital (Keefer and Knack, 1997; Mauro, 1995;

\footnotetext{
${ }^{\dagger}$ The authors are thankful to the three anonymous referees for their valuable comments which improved the paper significantly. We also like to thank the session chair Professor Kaushik Basu and the audience for their constructive comments to the earlier version of the paper presented at the $3^{\text {rd }}$ Development Economics Conference (DEC), Lincoln, 17-19 June 2019 and seminar participants of Institute of Southeast Asian Studies (ISAS), National University of Singapore and the New Zealand India Research Institute (NZIRI), Victoria University of Wellington New Zealand, for their useful comments and suggestions. We are also grateful to the Editor Professor Geoffrey Hodgson for his valuable comments for improving the paper.

(C) UNU-WIDER, 2020. Published by Cambridge University Press on behalf of Millennium Economics Ltd. This is an Open Access article, distributed under the terms of the Creative Commons Attribution-NonCommercial-ShareAlike licence (http://creativecommons.org/ licenses/by-nc-sa/4.0/), which permits non-commercial re-use, distribution, and reproduction in any medium, provided the same Creative Commons licence is included and the original work is properly cited. The written permission of Cambridge University Press must be obtained for commercial re-use.
} 
Reinikka and Svensson, 2005) and by leading to a misallocation of public expenditures away from growth-enhancing areas (such as education and health) towards areas which are less productivityenhancing, but are more corruption-intensive (such as large and expensive infrastructural projects) (Mauro, 1997; Tanzi and Davoodi, 1997). In this paper, we test for the corruption-growth relationship by using panel data for over 100 countries from 1984 to 2016, allowing this relationship to differ by political regime.

A vast empirical literature has studied the impact of corruption on growth. For example, Mauro (1995) finds that a one standard deviation increase in bureaucratic integrity will lead to a five percentage point increase in investment and an increase in the annual growth rate by half a percentage point. Fisman and Svensson (2001) estimate that a 1\% increase in corruption leads to a 3\% reduction in firm growth. Mo (2001) finds that a one percentage increase in the corruption level reduces the growth rate by about $0.72 \%$. Pellegrini and Gerlagh (2004) find that a one standard deviation decrease in corruption leads to an increase in growth of $1 \%$ per year, for a given initial income level.

Similarly, there is a large empirical literature on the effect of democracy on economic growth. In one of the early empirical contributions to this literature, Barro (1996) finds that the overall effects of democracy on growth are weakly negative using repeated cross-sections for 84 countries, with growth rates of GDP per capita averaged over 1965-75, 1975-85 and 1985-90. A similar finding is obtained by Tavares and Wacziarg (2001), also with cross-sectional data. On the other hand, Rodrik and Wacziarg (2005), Persson and Tabellini (2007) and Papaioannou and Siourounis (2008) find a positive effect using panel data. More recently, Acemoglu et al. (2014) find a sizeable and robust effect of democracy on economic growth using annual panel data and Generalized Method of Moments (GMM) methods for 175 countries for 1960-2010.

In this paper, we look at the joint effect of corruption and the type of political regime (dictatorship versus democracy) on economic growth. In other words, the joint effect examines if corruptiongrowth relationship varies in different political systems, i.e. in autocracy and democracy. A set of studies have highlighted the so-called 'East Asian Paradox', where countries in North and South East Asia grew rapidly in spite of high levels of corruption (Campos, 2002; Rock and Bonnett, 2004; Gill and Kharas, 2007). The observed positive relationship between corruption and growth has been attributed, at least in part, to the authoritarian regimes prevalent in these countries, which made sure that corruption was growth-enhancing. On the other hand, there are several autocratic regimes, mainly in Africa and Latin America, where high rates of corruption had a deleterious effect on economic growth (Bates, 1981; Bratton and Van de Walle, 1994; Haber, 2002).

To examine whether the corruption-growth relationship is different in autocracies than in democracies, we test for the relationship allowing it to differ by political regime. We use panel data for over 100 countries from 1984 to 2016. To test for the mediating effect of political regime on the corruption-growth relationship, we include an interaction term between our measure of democracy and of corruption, along with including the measures of corruption and democracy directly in the regressions we estimate.

We find clear and unambiguous evidence that the corruption-growth relationship differs by political regime, and that the growth-enhancing effect of corruption is more likely in autocracies than in democracies. The findings support the argument that credible commitment necessary for investment and growth is more likely in autocracies than democracies, and that corruption per se may not have a negative effect on growth if the deals made by politicians and firms are seen as credible.

The rest of the paper is in three sections. The next section discusses literature review; Section 3 presents our empirical model and the data to be used in the empirical analysis. Section 4 describes the results of the empirical analysis and Section 5 concludes.

\section{The relationship between corruption, political regimes and economic growth}

In this section, we review the theoretical and empirical literature on the relationship between corruption, political regimes and economic growth. 
From a theoretical standpoint, it is not clear whether the corruption-growth relationship will differ between democracies and autocracies, and if so, in which way. On one hand, the postulated negative effect of corruption on growth may be lower in an autocracy than in a democracy if the centralization of authority in the former regime leads to more efficient bribe-taking and lower loss of output (Ehrlich and Lui, 1999; Shleifer and Vishny, 1993). On the other hand, the possibility of the greater secrecy in corruption in an autocracy (as corruption includes all the actions taken to influence rule enforcers) (Campos and Giovannoni, 2017) allows for less growth-enhancing public and private investments which are not as corruption intensive than low-value projects in areas such as defence and infrastructure (Shleifer and Vishny, 1993), while the greater accountability pressures in a democracy limit the possibility of such growth-retarding investments. Aidt et al. (2008) provide a theoretical model which shows that in regimes where citizens cannot hold their political leaders to account (as in an autocracy), the political leadership may try and extract as much rent as possible from the formal sector, leading to an increase in the size of the informal sector, with a consequent negative effect on growth.

The heterodox economics literature has taken a different standpoint on the role of the political regime to mediate the effect of corruption on growth. It has argued that corruption is unlikely to negatively affect economic growth, especially in autocracies (Khan and Jomo, 2000). In some autocratic regimes, where ruling elites may have long-term time horizons, politicians are able to make the credible commitments to firms not to expropriate all of the rents that accrue from the investment decision, though some rent-sharing may exist in the form of bribes from firms to politicians (Bardhan, 1997; Khan 1996). Thus, bribe-taking by politicians from firms may not have a deleterious effect on investment and growth as deals offered by politicians to firms are likely to be 'ordered' - firms can be confident that politicians will deliver on the deals that they have entered into with them (Pritchett and Werker, 2013; Sen 2013). On the other hand, in democratic regimes, with frequent change of ruling parties, commitments made by politicians to firms are less likely to be credible. Here, bribe-taking by politicians is associated with deals that are 'disordered' as firms are less likely to believe that politicians are able to deliver on the deals offered to them. In this case, corruption is likely to have a deterring effect on growth.

The positive view in the heterodox literature on the growth-enhancing nature of corruption among autocracies draws primarily from the East Asian experience, and is not consistent with the experience of autocracies in Sub-Saharan Africa and South Asia, which have observed high rates of corruption and low rates of economic growth (Khan, 2006; Ndulu and O'Connell, 1999). Using case-study evidence from four African countries, Coolidge and Rose-Ackerman (1999) argue that where the autocrat is not confident of the length of his tenure (due to the fear of deposition from other factions in the ruling elite such as the military), he may engage in rent extraction from the private sector, leading to high corruption and low growth. In other words, if the autocrat has a sufficiently short time horizon, it would be in 'his interest to confiscate the property of his subjects, to abrogate any contracts he has signed in borrowing money from them, and generally to ignore the long-run economic consequences of his choices' (Olson, 1993: 572).

This suggests that the crucial distinguishing feature between the authoritarian regimes in East Asia as compared to the authoritarian regimes in other parts of the developing world is that the leaders in East Asia had an interest in providing a stable economic environment for the private sector to take long-term investment decisions, even though the relations between the state and the private sector were of the "crony capitalist' variety. Such collusive relations between government and business provided security for corrupt payments, so that corruption acted as 'the grease in the wheels' in these countries. Therefore, the key mechanism by which corruption was growth-enhancing in East Asian autocracies as compared to other autocracies was the East Asian autocrat's credible commitment to economic freedom and probusiness policies, thereby providing confidence to the firms to invest, leading to long-term growth (Saha et al., 2014). ${ }^{1}$ We test for the presence of this mechanism explicitly in our empirical analysis.

\footnotetext{
${ }^{1}$ In many market-oriented economies, government restrictions on economic activity breed rents in various forms, and people often compete for the rents (Krueger, 1974), hence engendering varying degrees of corruption. Rose-Ackerman (1978)
} 


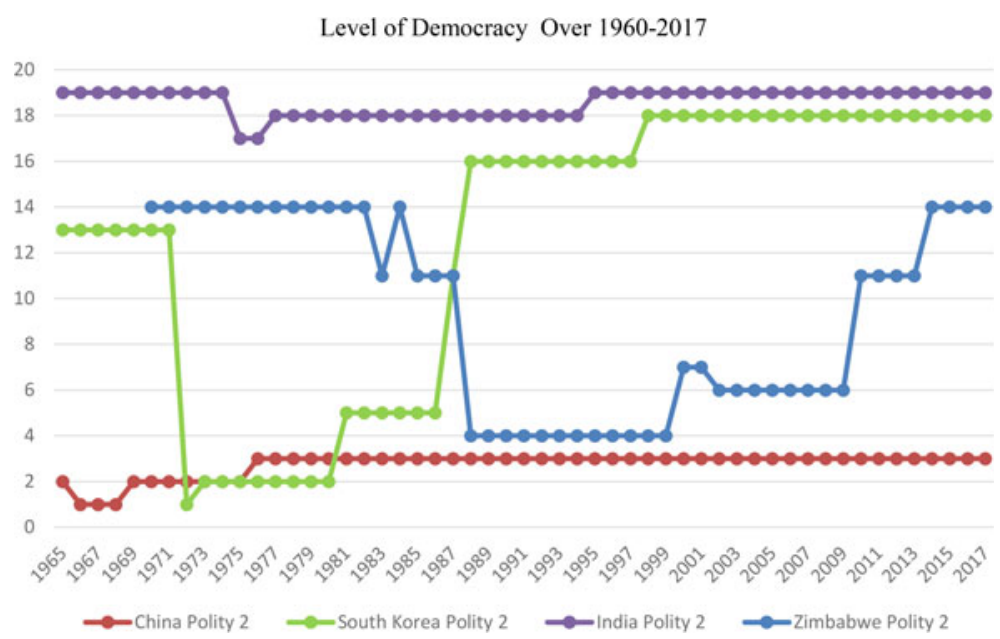

Figure 1. Evolution of democracy in China, India, South Korea and Zimbabwe.

Note: We use the Polity2 measure of democracy. We re-scale the measure from -10 to +10 to 0 to 20 , with higher values of the measure capturing higher levels of democracy. A score of 0-10 implies autocracy while a score of 10-20 implies democracy. India has always been a democracy from 1965 to 2017, South Korea briefly from 1965 to 1970, and then from 1987 onwards. China has never been a democracy. Zimbabwe was under autocracy since the mid-80s till the end of 2010.

Source: Authors' calculation.

There are few quantitative cross-country studies on the inter-relationship between corruption, political regimes and growth. Mendez and Sepulveda (2006) find that there is a non-monotonic relationship between corruption and growth, with corruption beneficial for economic growth at low levels of incidence and detrimental at high levels of incidence. They also find that in political regimes that are 'not free', corruption does not affect economic growth in the same fashion as for 'free' political regimes, and that the non-monotonic relationship between corruption and growth is observed only in 'free' countries. Assiotis and Sylwester (2014) find that while corruption does have a negative effect on growth, this is more likely to be observed in autocracies. Similarly, Meon and Sekkat (2005) show that while corruption has a negative effect on growth, it is particularly true for countries with weak governance quality (see also Berggren et al., 2012).

The argument that corruption may be beneficial to growth in autocracies as compared to democracies finds strong support in qualitative country case-studies. In the case of South Korea, an authoritarian regime since 1963, with the coming to power of the military general Park Chung-heee, till democratization in 1987, there was wide spread corruption in the period of authoritarian rule in 1963-1987 (see Figure 1). This was also the period of rapid growth of the Korean economy. During the autocratic period, personal ties between the business elite and the political elite and the mutual advantage that the system of exchanging bribes for political favours to the Korean conglomerates provided to both political and economic elites underpinned institutions of credible commitment ('ordered deals') in Korea all through the 1960s to the 1980s, and was crucial for Korea's success in the early stage of growth, in a context where the rule of law in Korea was vague and seldom enforced (Kang, 2002a, 2002b). As Figure 2 makes clear, high growth in Korea in the 1980s (and earlier)

first argued that competition between officials keeps the level of bribe relatively low and may eliminate entirely due to the possibility of overlapping jurisdictions, i.e. low bribe returns and the honesty of some officials may push the market-clearing bribe-price still lower, inducing other officials to give up corruption. Hence, economic liberalisation can foster economic competition and ease of doing business and promote growth. Some observed evidence support this view. Some countries with a very low level of democracy enjoy a very high level of economic freedom and growth, say South Korea in the 1960s and 1970s and China. On the other hand, in spite of India's high level of democracy, it experiences a low level of economic freedom and a high level of corruption. 


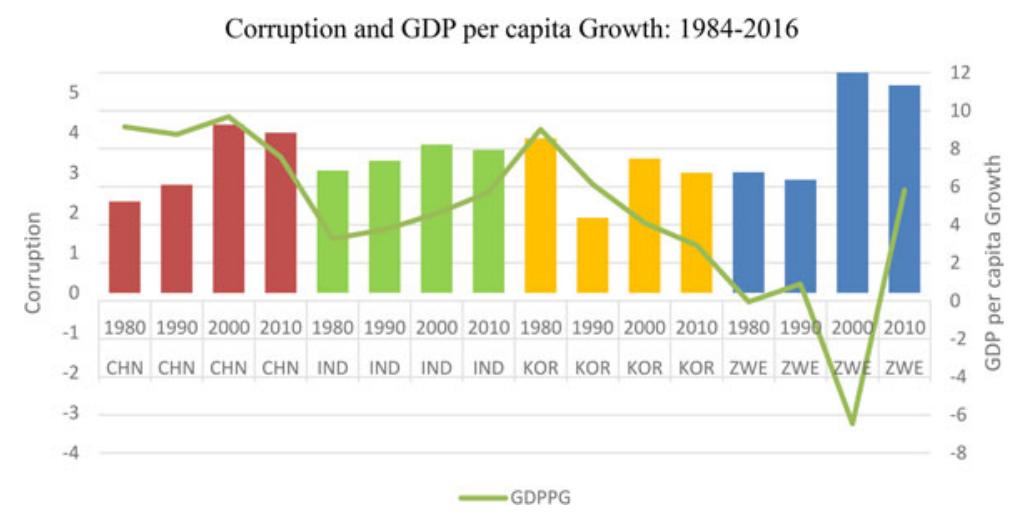

Figure 2. Corruption and per capita GDP growth: China, India, South Korea and Zimbabwe. Source: Authors' calculation.

coincided with high levels of corruption. Therefore, in South Korea in the 1960s and 1970s, 'development and money politics proceeded hand in hand' (Kang, 2002a: 185).

China is also an example of an autocratic country which has witnessed high rates of economic growth along with high rates of corruption (see Figures 1 and 2). The corruption that China witnessed took the form of profit sharing where both elites and non-elites benefited from wealth creation in their jurisdictions (Ang, 2020: 12). As Ang (2019) argues, corruption spurred 'politically connected politically connected capitalists to feverishly invest and build, while enabling politicians to achieve their development targets and ascend career ladders'. Therefore, the Chinese leadership took strong methodological measures to curb the growth-damaging effects of corruption.

Zimbabwe provides an interesting counter-example of an autocracy which was highly corrupt but where corruption was growth-retarding, unlike the case of South Korea and China (as Figure 1 shows, Zimbabwe has remained an autocracy since the 1960s). Here, the ruling elite placed its own political survival and control above policies of economic growth. Thus, Zimbabwe's ruling party, the ZANU-PF, under the leadership of Robert Mugabe, used 'the strength of the inherited state apparatus to suppress political opposition and to curtail the independent economic power of business elites' (Bratton and Masunungure, 2011:3.). At the same time, the quest for political power led to open corruption and nepotism (Mandaza, 1986). Therefore, Zimbabwe illustrates the example of an autocracy where economic freedom was curtailed, leading to low economic growth, co-existing with high levels of corruption (as evident in Figure 2).

In contrast to South Korea, China and Zimbabwe, India has been a democracy ever since it became independent in 1947 (Figure 1). In the first three decades after independence, the Indian government created one of the most comprehensively controlled and regulated economies after independence. As a consequence, 'the Indian elite developed a highly sophisticated mode of discrete lobbying designed to achieve particularistic benefits from the new permit, licence, quota raj. Each major business house established the equivalent of an industrial embassy designed to act as a listening post, liaison office and lobbying agency to deal with political and bureaucratic decision makers' (Kochanek, 1996: 157). There was very little mutual confidence between the government and business sector, leading to a lack of trust by the business sector on the deals that the state might offer to them. As Bhagwati (1993) points out, 'the industrial-cum-licensing system ... had degenerated into a series of arbitrary, indeed inherently arbitrary, decisions where, for instance, one activity would be chosen over another simply because the administering bureaucrats were so empowered, and indeed obligated, to choose' (p. 50). This led to a 'disordered deals' environment that contributed significantly to low rates of private investment and slow economic growth all through the 1960s and 1970s (Kar and Sen, 2016). As Bardhan (1984) argues, the tensions that were inherent in India's democracy that led to the management of conflict in the ruling coalition/dominant proprietary classes (comprising the industrial 
capitalists, the agrarian elite and the professional class) resulted in an increasing share of nondevelopment expenditures such as subsidies to the dominant proprietary classes. This left limited resources for productive capital formation by the public sector, thereby constraining economic growth. Therefore, in the Indian case, while there were high rates of corruption (see Figure 2), this did not lead to high economic growth as in the South Korean and Chinese cases.

These case-studies show that the effects of corruption on growth are likely to differ by political regime, and autocracies such as China and South Korea may have certain characteristics (a high level of economic freedom) that may make the effect of corruption on growth more benign as compared to a democracy like India, and autocracies which lack economic freedom such as Zimbabwe. We investigate this proposition next more systematically using cross-country panel data.

\section{Empirical model, methodology and data}

This section discusses model, methodology and data used to explore the association between corruption and growth.

\subsection{Model}

Our panel data analysis based on standard economic growth model expresses the rate of per capita income (growth) as dependent on various macroeconomic factors such as investment, population growth and average school enrolment. To examine the role of corruption and political regimes, we follow the standard approach of estimating growth regressions, by developing a Barro-style augmented growth model as an extension of Solow (1956). In the original Solow model, output/income in an economy over the long-term depends on its available factors of production and technology. Following Barro (1991), we extend the Solow growth model by including corruption, democracy and the interaction term to explore the joint effects of corruption and regime type on economic growth. We also include openness (economic freedom) and money supply to measure the impact of globalization and macroeconomic stability in a country. The interaction effects measuring the effect of corruption on economic growth in different regime types are the main focus of this study.

The base model using panel data over the period 1984-2016 is structured as follows:

$$
\begin{aligned}
\mathrm{LRGDPPC}_{i t}= & \propto_{0}+\propto_{1} \mathrm{CORR}_{i t}+\propto_{2} \mathrm{DEMO}_{i t}+\propto_{3} \mathrm{CORR}_{i t} \times \mathrm{DEMO}_{i t} \\
& +\propto_{4} \log \left(\frac{\mathrm{CAP}}{\mathrm{POP}}\right)_{i t}+\propto_{5} \mathrm{EDU}_{i t}+\propto_{6} \mathrm{RND}_{i t}+\propto_{7} \mathrm{OPEN}_{i t}+\propto_{8} \mathrm{M}_{2} \mathrm{GDP}_{i t}+\varepsilon_{i t}
\end{aligned}
$$

where, LRGDPPC is log of real per capita gross domestic product as a measure of economic growth, CORR is corruption, DEMO is democracy indices, CAP is capital per capita, RND is research and development, EDU is educational attainment, OPEN (EF) is trade openness (economic freedom), M2GDP is money supply to GDP ratio, $\varepsilon$ is error term. Subscripts $i$ is country and $t$ is for time.

The sign and significance of $\alpha_{3}$ is of interest, which captures the interaction effect of corruption and democracy on log of per capita income. In addition, the marginal effects of corruption and democracy on income are computed as follows:

$$
\begin{aligned}
& \frac{\operatorname{LRGDPPC}_{i t}}{\partial \mathrm{CORR}_{i t}}=\propto_{1}+\propto_{3} \mathrm{DEMO}_{i t} \\
& \frac{\partial \mathrm{LRGDPPC}_{i t}}{\mathrm{DDEMO}_{i t}}=\propto_{2}+\propto_{3} \mathrm{CORR}_{i t}
\end{aligned}
$$


Equation (2a) demonstrates the marginal impact of corruption on income in the presence of democracy. If $\alpha_{3}<0$, then equation (2a) implies that a one unit increase in CORR yields a greater reduction in income as the degree of democracy expands. ${ }^{2}$ Alternatively, an increase in corruption level enhances growth when countries are strongly autocratic or less democratic. Contrarily, if $\alpha_{3}>0$, a higher level of corruption increases growth with a greater democracy. In other words, the marginal effect of corruption and democracy reveals that an increase in the level of corruption on income per capita growth depends on the level of political regime, the impact of corruption on growth is favourable in autocracy and the opposite is true in greater democracy. Likewise, equation (2b) is the marginal effect of democracy in the presence of a corrupt system. If $\alpha_{3}<0$ and exceeds $\alpha_{2}>0$ then a one unit increase in the level of democracy lowers growth in a more corrupt nation.

Following neo-classical growth theory, it is expected that a greater stock of capital per capita, higher educational achievement and more research and development should boost income growth (Mankiw et al., 1992; Romer, 1990). Hence, $\alpha_{4}, \alpha_{5}$ and $\alpha_{6}$ are expected to be positive. Rent-seeking theory and cognitive rules in the context of a market for ideas suggest that the impact of open market should have a positive impact on growth (Krueger, 1974; Greif and Mokyr, 2017), we expect $\alpha_{7}$ to be positive. Finally, following the basic macroeconomic model, the circular flow diagram suggests a greater money supply increases income as it is an injection. Hence, the expected sign of $\alpha_{8}$ is positive.

This is to note here that as our empirical model uses panel fixed effects (FE), different from Mauro (1995), which uses GDP per capita growth rate as a dependent variable and includes the initial level of GDP per capita as an explanatory variable in the model. The Mauro growth model analyses corruption-growth relationship for a cross-section of around 70 countries for the average per capita growth over 1960-1985, while we use panel data in our estimation. However, as a robustness check, we replace GDP per capita with its growth rate as the dependent variable with the initial level of GDP per capita as a control variable and the estimations are run using OLS (for the cross-section of countries for the average growth per capita over 1984-2016) and panel period FE. In addition, two-way FE are estimated with GDP per capita as a dependent variable with lagged GDP per capita as a control variable. For further robustness checks and to address the endogeneity issue, DynamicPanel-System-GMM with GDP per capita growth as the dependent variable is also estimated.

\subsection{Methodology}

In order to test the proposed hypothesis, a panel estimation technique is used for over 100 countries for the period 1984-2016. We first start employing an ordinary least-square estimation with the average values of each variable for the period 1984-2016. Following Saha and Gounder (2013), a sevenperiod panel (i.e. five 5-year average for 1995-2013 and a 3-year average for 2014-16) is estimated to defecate potential business cycle effects that are assumed to be present in annual data. Then we examine the FE model with country- and time-specific variations in corruption-growth relationship. Next we test its validity, comparing the variances of parameters obtained from the random-effect model using the Hausman test. According to Baltagi (2008) and Basu et al. (2019), all estimators in the FE model even with a small number of cross-sections $N$ are consistent as time $(t)$ increases and approaches to infinity. In the random-effects model, with the regression error term $v_{i, t}=u_{i}+\varepsilon_{i, t}$, where $u_{i}$ is the time-invariant random individual effect in addition to $\varepsilon_{i, t}$ error term denoting all other missing elements. Furthermore, in both models (random effects and FE), it is assumed that all explanatory variables are independent of error terms $v_{i t}, u_{i}$, and identically distributed (i.i.d) and assumed to be normally distributed. The results are presented after correcting for both heteroscedasticity and serial correlation with robust standard errors.

Also, while the simple least-squares panel data model with FE provide an important insight on the coefficients of interest, they can render biased estimates due to the potential problem of endogeneity between several of our variables such as growth and democracy, growth and corruption, which can

${ }^{2}$ The corruption index ranges from zero to six and a higher value indicates a higher level of corruption. 
cause the error terms to be correlated with dependent variables. ${ }^{3}$ Although a vector of control variables is used to reduce the problem of endogeneity, there still could be omitted variables that cause changes in both corruption and growth.

There is a clear reverse causality issue between the institutional variables (corruption, democracy and the interaction term between corruption and democracy), and the dependent variable - economic growth. The usual approach to resolve the endogeneity issue is to use two-stage-least square (TSLS) which uses an instrumental variable that is correlated with the independent variable but not with the dependent variable. However, it is extremely difficult to find efficient instruments. Following Mauro (1995), the potential issue of simultaneous causation is addressed here using the TSLS procedure and employing instrumental variables that may affect institutional variables but not affect growth directly. Ethnic tensions (ET), which focuses on the degree of tension within a country attributable to racial, nationality, or language divisions, is used as an instrument for institutional variable such as corruption. This is similar to Mauro (1995) who uses ethnolinguistic fractionalization as instruments for corruption and points out that the extent to which countries are fractionalized along ethnolinguistic lines is exogenous and unrelated to economic variables other than through its effects on institutional efficiency. ${ }^{4}$ The raw data also confirm that the correlation between real GDP per capita growth and ET is -0.072 but the correlation between ET and corruption is 0.341 (Appendix Table A3). We also use lag of the other right-hand side variables as instruments. ${ }^{5}$

For a further robustness check, System-GMM-Dynamic-Panel is also employed to address the endogeneity issue. System-GMM estimators improve the efficiency of estimates by using extra moment conditions that 'rely on certain stationarity conditions of the initial observation.' (see Blundell and Bond, 1998). Identification is based on first-differencing and using lagged values of the endogenous variables as instruments. The System-GMM estimator (GMM-SYS) is composed of a difference equation instrumented with lagged levels and additionally a level equation, which is estimated using lagged differences as instruments (Bond et al., 2001; Rajan and Subramanian, 2008). Hence, SystemGMM-Dynamic-Panel is used to address the endogeneity issue for the robustness check. We test the instrument validity by using Hansen's $J$ statistic of over-identifying restrictions.

\subsection{Data}

The empirical model employs macroeconomic data, corruption indices and democracy indicators to test the proposed hypothesis.

\subsubsection{Corruption data}

The major obstacles of comparative studies of corruption have been the lack of a general definition of corruption and the absence of objective cross-national data on corrupt behaviour given its illegal and secret nature. The subjective measure of corruption is used as a principal measure, source from International Country Risk Guide (ICRG). The ICRG index is constructed by Political Risk Services. ${ }^{6}$ It measures the corruption within the political system that threatens foreign investment by distorting the economic and financial environment and reducing the efficiency of government and business by enabling people to assume positions of power through patronage rather than ability. The ICRG corruption index (CORR) has been widely used in the literature and it is published since $1984 .^{7}$ For simplicity and ease of exposition, the ICRG index has been converted into a scale from zero (least corrupt) to six (most corrupt).

\footnotetext{
${ }^{3}$ Democracy and corruption are endogenously determined in the sense that they are both correlated with exogenous shocks that affect the growth of real GDP per capita.

${ }^{4}$ However, ethnolinguistic fractionalization is only available for cross-section of countries, which Mauro (1995) uses in the cross-section studies. In contrast, Ethnic tension variable is available over time and suitable for panel data analysis.

${ }^{5}$ The results are available upon request from the authors.

${ }^{6}$ The definition of corruption used is the misuse of public office for private enrichment in this study. See the Political Risk Services (PRS) http://www.prsgroup.com/countrydata.aspx.

${ }^{7}$ See Swaleheen (2011) and Dal BÓ and Rossi (2007) for details.
} 
We also use Transparency International's (TI's) corruption perception index (CPI) for robustness check. The CPI index is a composite index based on individual surveys from different sources. The index is rescaled and ranges from zero to 10 and a higher value indicates a higher level of corruption. The index is available since 1995 .

\subsubsection{Democracy indicators}

Like corruption, democracy also suffers from the problem of measurement. The measurement of democracy is disputed due to the problems of conceptualization, measurement and aggregation and no single index offers a satisfactory response to these problems, and even the best indices have significant weaknesses (Coppedge, 2002; Munck and Verkuilen, 2002). For the purpose of this study, ICRG democratic accountability is used as a principal measure of democracy (DEMO). It is a measure of how responsive government is to its citizens and it is more likely that a less responsive government will fall, peacefully in a democratic society, but possibly violently in a non-democratic one. The score for the democracy index ranges from zero to six, higher values signalling dominated democracy. The Polity 2 institutionalized measure of democracy index from Polity 4 dataset is used as an alternative measure of democracy. The index is based on the competitiveness of political participation, the openness and competitiveness of executive recruitment and constraints on the chief executives. ${ }^{8}$ It measures the degree of democracy and autocracy. The most widely used Polity score combines the scores on the democracy and autocracy indices to a single regime indicator. The score captures the regime authority spectrum on a 21-point scale ranging from -10 (hereditary monarchy) to +10 (consolidated democracy). For ease of explanation, we rescaled the index from 1 to 21 and a higher value indicates a higher level of democracy.

\subsubsection{Macroeconomic data}

Real GDP per capita is the dependent variable. The real GDP per capita, capital formation, research and development expenditure to GDP, educational attainment and money supply (M2) to GDP data are obtained from the World Bank's World Development Indicators (WDI) database. For the purpose of the study, the economic freedom index is used along with the openness variable and the data are from the Heritage Foundation. ET data for the instrumental variable are from ICRG index, Political Risk Services. Due to missing data, the total number of countries used in any regression ranges from 103 to 136 for the period 1984-2016. The summary statistics and data description and sources are presented in Appendix Tables A1 and A2, respectively.

\section{Empirical results}

We start our investigation with the Kernel-fit of the scatter-plots of the relationship between per capita real GDP with corruption democracy. The Kernel-fit line depicting the relationship between LGDPPC and CORR indicates that corruption lowers per capita income (Figure 3a). In other words, a higher income growth is associated with low levels of corruption. For instance, the average level of income per capita for the period 1984-2016 in China is around US\$2,520, and the corruption score is 2.26, whereas, the income per capita and corruption level in Congo Democratic Republic are US $\$ 456$ (approx.) and 5.26, respectively. ${ }^{9}$ The results support the common claim that less corruption enhances economic growth. ${ }^{10}$ Both ICRG and TI CPIs support the results.

However, Figure $3 \mathrm{~b}$ shows a U-shaped relationship between LGDPPC and DEMO (for both the democracy indices) suggesting that some autocratic countries are performing well in terms of growth along with their democratic counterparts. In other words, there is a high level of income both at a greater level of autocracy and democracy but the income level decreases at the transition stage in

\footnotetext{
${ }^{8}$ See http://www3.nd.edu/ mcoppedg/crd/PolityIVUsersManualv2002.pdf for details.

${ }^{9} \mathrm{~A}$ higher value of corruption indicates more corruption.

${ }^{10}$ See, for example, Mauro (1995).
} 

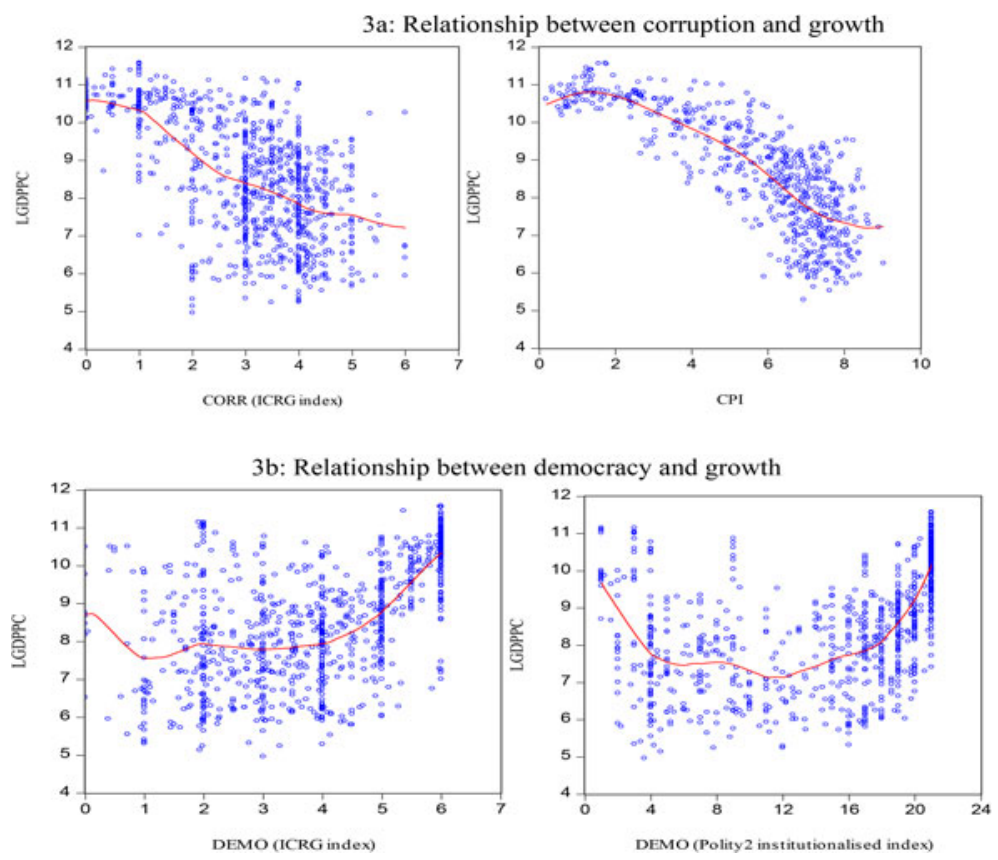

Figure 3. Kernel fit plots for the relationship between corruption, democracy and growth. (a) Relationship between corruption and growth. (b) Relationship between democracy and growth.

the process of democratization. On the one hand, countries with greater democracy exhibit higher income (such as Australia and United Kingdom). Likewise, countries with stronger autocracy also demonstrate a higher income (e.g. Brunei and Saudi Arabia). On the other hand, per capita income levels of the transition countries (i.e. from autocracy to democracy) such as Russia and Tunisia are quite low. However, countries with a very high level of democracy enjoy very high income compared to the strong autocratic countries. This result supports the widespread argument in the existing democracy literature that democracy provides the best opportunities for growth (e.g. Jalles, 2010; Barro, 1991). However, in order to get the firmer support of the results, one should rigorously test whether the change in coefficients is significant or not. In addition, we also explore the interaction effect of corruption and democracy on economic growth to estimate the joint effect of democracy and corruption on growth.

\subsection{Regression results}

The estimated regression coefficients using ICRG corruption and democracy indices for the base model in equation (1) are reported in Table 1. The OLS regression results without controls suggest that corruption coefficient is negative and significant but the coefficients for democracy and the interaction term are positive but insignificant (column 1, Table 1). However, the results with control variables show that the coefficient of corruption is positive but not significant indicating that there is not enough evidence that corruption is growth-enhancing. The coefficient for democracy is positive and significant at the 5\% level, suggesting that a greater democracy enhances growth (column 2, Table 1). This result supports the findings of Alfonso-Gil et al., (2014) and Benyishay et al., (2010), which show that movements towards higher levels of civil liberty are associated with higher economic growth rates. Moreover, Cooray et al. (2017) find that a free press improves the government's accountability to the society and leads to better governance mostly in the developed countries. 
Table 1. Growth-corruption relationship: 1984-2016

\begin{tabular}{|c|c|c|c|c|c|c|c|c|c|}
\hline & \multicolumn{9}{|c|}{ ICRG democracy index } \\
\hline & \multicolumn{3}{|c|}{ OLS (average over 1984-2016) } & \multicolumn{3}{|c|}{ 5-year average panel least square } & \multicolumn{3}{|c|}{ 5-year average panel fixed effects } \\
\hline & (1) & $(2)$ & (3) & (4) & (5) & (6) & (7) & (8) & (9) \\
\hline Corruption & $\begin{array}{l}-0.891^{\star \star \star} \\
(0.306)\end{array}$ & $\begin{array}{l}0.051 \\
(0.347)\end{array}$ & $\begin{array}{l}0.032 \\
(0.343)\end{array}$ & $\begin{array}{r}-0.0877 \\
(0.230)\end{array}$ & $\begin{array}{l}0.204 \\
(0.246)\end{array}$ & $\begin{array}{l}0.206 \\
(0.245)\end{array}$ & $\begin{array}{l}0.060 \\
(0.062)\end{array}$ & $\begin{array}{l}0.144^{\star \star} \\
(0.073)\end{array}$ & $\begin{array}{l}0.149^{\star \star} \\
(0.073)\end{array}$ \\
\hline Democracy & $\begin{array}{l}0.089 \\
(0.219)\end{array}$ & $\begin{array}{l}0.497^{\star \star} \\
(0.246)\end{array}$ & $\begin{array}{l}0.480^{\star *} \\
(0.245)\end{array}$ & $\begin{array}{l}0.585^{\star \star \star} \\
(0.174)\end{array}$ & $\begin{array}{l}0.625^{\star \star *} \\
(0.182)\end{array}$ & $\begin{array}{l}0.626^{\star \star \star} \\
(0.181)\end{array}$ & $\begin{array}{l}0.009 \\
(0.012)\end{array}$ & $\begin{array}{l}0.087 \\
(0.056)\end{array}$ & $\begin{array}{l}0.093^{*} \\
(0.057)\end{array}$ \\
\hline Corruption $\times$ Democracy & $\begin{array}{l}0.010 \\
(0.053)\end{array}$ & $\begin{array}{l}-0.155^{\star \star *} \\
(0.060)\end{array}$ & $\begin{array}{l}-0.151^{\star \star \star} \\
(0.060)\end{array}$ & $\begin{array}{c}-0.097^{\star *} \\
(0.041)\end{array}$ & $\begin{array}{l}-0.155^{\star * *} \\
(0.045)\end{array}$ & $\begin{array}{l}-0.154^{\star \star *} \\
(0.045)\end{array}$ & $\begin{array}{l}-0.004 \\
(0.003)\end{array}$ & $\begin{array}{r}-0.025^{\star} \\
(0.054)\end{array}$ & $\begin{array}{r}-0.027^{\star} \\
(0.015)\end{array}$ \\
\hline $\begin{array}{l}\text { Corruption } \times \text { Democracy } \times \text { East } \\
\text { Asia }\end{array}$ & & & $\begin{array}{l}-0.052 \\
(0.063)\end{array}$ & & & $\begin{array}{l}-0.017 \\
(0.016)\end{array}$ & & & $\begin{array}{l}0.011^{\star *} \\
(0.005)\end{array}$ \\
\hline Capital per capita & & $\begin{array}{l}0.049^{\star \star \star} \\
(0.019)\end{array}$ & $\begin{array}{l}0.054^{\star \star \star} \\
(0.018)\end{array}$ & & $\begin{array}{l}0.031^{\star *} \\
(0.013)\end{array}$ & $\begin{array}{l}0.033^{\star \star *} \\
(0.013)\end{array}$ & & $\begin{array}{l}0.283^{\star \star *} \\
(0.054)\end{array}$ & $\begin{array}{l}0.281^{* * *} \\
(0.054)\end{array}$ \\
\hline Educational attainment & & $\begin{array}{l}0.183^{\star \star \star} \\
(0.050)\end{array}$ & $\begin{array}{l}0.184^{\star \star \star} \\
(0.049)\end{array}$ & & $\begin{array}{l}0.145^{\star \star \star} \\
(0.037)\end{array}$ & $\begin{array}{l}0.146^{\star \star \star} \\
(0.037)\end{array}$ & & $\begin{array}{l}0.008 \\
(0.007)\end{array}$ & $\begin{array}{l}0.007 \\
(0.007)\end{array}$ \\
\hline Openness/Economic Freedom & & $\begin{array}{l}0.508^{\star \star \star} \\
(0.191)\end{array}$ & $\begin{array}{l}0.471^{\star \star} \\
(0.195)\end{array}$ & & $\begin{array}{l}0.266^{\star} \\
(0.150)\end{array}$ & $\begin{array}{l}0.258^{\star} \\
(0.150)\end{array}$ & & $\begin{array}{l}0.004 \\
(0.003)\end{array}$ & $\begin{array}{l}0.004^{\star} \\
(0.003)\end{array}$ \\
\hline Money supply (\% of GDP) & & $\begin{array}{l}0.008^{\star \star \star} \\
(0.003)\end{array}$ & $\begin{array}{l}0.009^{\star \star \star} \\
(0.003)\end{array}$ & & $\begin{array}{l}0.009^{\star \star \star} \\
(0.002)\end{array}$ & $\begin{array}{l}0.010^{\star \star \star} \\
(0.002)\end{array}$ & & $\begin{array}{l}0.002^{\star \star \star} \\
(0.001)\end{array}$ & $\begin{array}{l}0.002^{\star \star \star} \\
(0.001)\end{array}$ \\
\hline Constant & & $\begin{array}{l}2.663 \\
(1.953)\end{array}$ & $\begin{array}{l}2.744 \\
(1.937)\end{array}$ & $\begin{array}{l}7.568^{\star \star \star} \\
(0.992)\end{array}$ & $\begin{array}{l}3.463^{\star \star \star} \\
(1.254)\end{array}$ & $\begin{array}{l}3.433^{\star \star \star} \\
(1.247)\end{array}$ & $\begin{array}{l}8.053^{\star \star \star} \\
(0.218)\end{array}$ & $\begin{array}{l}5.544^{\star \star \star} \\
(0.413)\end{array}$ & $\begin{array}{l}5.533^{\star \star \star} \\
(0.414)\end{array}$ \\
\hline No. of observations & 136 & 108 & 108 & 894 & 480 & 480 & 856 & 410 & 410 \\
\hline Adjusted $R^{2}$ & 0.482 & 0.562 & 0.536 & 0.406 & 0.537 & 0.538 & 0.515 & 0.769 & 0.771 \\
\hline Wald statistics & 102.70 & 55.20 & 47.57 & 99.12 & 47.63 & 42.00 & 24.50 & 32.69 & 30.99 \\
\hline
\end{tabular}

Note: Robust standard errors are in parentheses with robust standard errors. (ii) ${ }^{* * * * * * *}$ indicate significance level at the $1 \%, 5 \%$ and $10 \%$, respectively. 
The coefficient for the interaction term between corruption and democracy is negative and significant at the $1 \%$ level of significance illustrating that democracy and corruption together have significant damaging effects on economic growth in a country (column 2, Table 1). It suggests that the effect of corruption on growth is less positive as the level of democracy expands. A one unit increase in corruption level reduces log real GDP per capita by $155 \%$. Based on equation (2a), the interaction effect of corruption on real GDP per capita at the mean score of democracy of 3.81 is -5.85 , which is significant, suggesting that a one standard deviation point increase in CORR increases economic growth by 6.51 points at the mean democracy index. The impact of corruption on economic growth demonstrates some mixed effects. If a country is more autocratic, then more corruption is associated with higher growth. Alternatively, the effect of corruption on growth is less positive as the level of democracy expands. On the other hand, the interaction effect of democracy on real GDP per capita (equation (2a)) at the mean corruption score 3.07 is 0.02 indicating that a one standard deviation point increase in democracy (DEM) increases economic growth by 0.028 points at the mean corruption index. Like corruption, democracy also illustrates the mixed effects on income growth, democracy stimulates (dampen) growth when corruption is low (high). In other words, corruption shows positive effect if a country is more autocratic. But if a country has more corruption, then more democracy is growth-inhibiting. The results of these two interactive factors are interpreted in detail in the partial (marginal) effect estimation.

The panel least-square and two-way FE results both with and without control variables confirm the OLS results that corruption is growth-enhancing in autocracies (columns $4-5$ and 7-8, Table 1 ). Moreover, the magnitude of the coefficient of the interaction term increases after including the control variables. Control variables are expected in signs, such as higher stock of capital per capita, educational attainment, research and development expenditure, more open economy and money supply increase the rate of per capita income. One should note that due to the large number of missing values of research and development expenditure data, which reduces the number of observations significantly, we reported the results without research and expenditure variable. The results remain the same when the ICRG democracy index is replaced by Polity2 measure of institutionalized democracy indicator (Polity4 dataset) (Table 2).

\subsection{The East Asian paradox}

East Asian countries present a number of puzzles and paradoxes mainly due to the fact that the growth rates in East Asia have greatly exceeded all other regions of the world. The current economic wisdom holds that, ceteris paribus, higher levels of corruption should be associated with lower rates of development (e.g. Mauro, 1995). East Asian countries do not follow the wisdom and the economic success is paradoxical because most of the countries in the region have been plagued by relatively serious highlevel corruption throughout the period of rapid growth and the political environment in the region is mostly autocratic. The average level of corruption and GDP per capita growth over the period 19842016 in Table 3 show that some East Asian countries enjoy a high level of economic growth in spite of having a high level of corruption (such as China and South Korea). The East Asian paradox is tested using interaction among East Asian dummy variable and corruption and democracy variables. The FE result confirms that the interaction effect between corruption and democracy is positive (column 9, Table 1) in East Asian countries confirming the paradox that countries in East Asian countries grow faster despite the high level of corruption and restricted democracy. Both ICRG and Polity2 measure of institutional democracy indices support these results.

\subsection{Robustness tests}

\subsubsection{Dependent variable GDP per capita growth}

The results using GDP per capita growth as a dependent variable using the Barro type growth regression with initial GDP per capita as independent variable confirms the convergence theory of growth as the coefficient of initial GDP per capita (Barro, 1991) is negative and significant at the 1\% level (not 
Table 2. Growth-corruption relationship: 1984-2016

\begin{tabular}{|c|c|c|c|c|c|c|c|c|c|}
\hline & \multicolumn{9}{|c|}{ Polity2 measure of institutionalized democracy index (Polity4 dataset) } \\
\hline & \multicolumn{3}{|c|}{ OLS (average over 1984-2016) } & \multicolumn{3}{|c|}{ 5-Year average panel least square } & \multicolumn{3}{|c|}{ 5-Year average panel fixed effects } \\
\hline & $(1)$ & $(2)$ & (3) & (4) & (5) & (6) & (7) & (8) & (9) \\
\hline Corruption & $\begin{array}{r}-0.590 \\
(0.410)\end{array}$ & $\begin{array}{l}0.452 \\
(0.386)\end{array}$ & $\begin{array}{l}0.453 \\
(0.387)\end{array}$ & $\begin{array}{l}0.085 \\
(0.215)\end{array}$ & $\begin{array}{l}0.153 \\
(0.261)\end{array}$ & $\begin{array}{l}0.155 \\
(0.260)\end{array}$ & $\begin{array}{l}0.022 \\
(0.060)\end{array}$ & $\begin{array}{l}0.144^{* *} \\
(0.073)\end{array}$ & $\begin{array}{l}0.149^{* *} \\
(0.073)\end{array}$ \\
\hline Democracy & $\begin{array}{l}0.072 \\
(0.078)\end{array}$ & $\begin{array}{l}0.206^{\star \star \star} \\
(0.076)\end{array}$ & $\begin{array}{l}0.207^{\star \star \star} \\
(0.076)\end{array}$ & $\begin{array}{l}0183^{\star \star \star} \\
(0.044)\end{array}$ & $\begin{array}{l}0.146^{\star \star \star} \\
(0.058)\end{array}$ & $\begin{array}{l}0.147^{\star \star \star} \\
(0.058)\end{array}$ & $\begin{array}{l}0.024 \\
(0.043)\end{array}$ & $\begin{array}{l}0.087 \\
(0.056)\end{array}$ & $\begin{array}{l}0.093^{\star} \\
(0.057)\end{array}$ \\
\hline Corruption $\times$ Democracy & $\begin{array}{c}-0.018 \\
(0.021)\end{array}$ & $\begin{array}{l}-0.064^{\star \star \star} \\
(0.020)\end{array}$ & $\begin{array}{l}-0.063^{\star \star \star} \\
(0.020)\end{array}$ & $\begin{array}{l}-0.041^{\star \star \star} \\
(0.011)\end{array}$ & $\begin{array}{l}-0.042^{\star \star \star} \\
(0.013)\end{array}$ & $\begin{array}{l}-0.042^{\star \star \star} \\
(0.013)\end{array}$ & $\begin{array}{r}-0.003 \\
(0.012)\end{array}$ & & $\begin{array}{c}-0.027^{\star} \\
(0.015)\end{array}$ \\
\hline Corruption $\times$ Democracy $\times$ East Asia & & & $\begin{array}{c}-0.011 \\
(0.014)\end{array}$ & & & $\begin{array}{c}-0.004 \\
(0.004)\end{array}$ & & & $\begin{array}{l}0.011^{\star \star} \\
(0.005)\end{array}$ \\
\hline Capital per capita & & $\begin{array}{l}0.043^{* *} \\
(0.018)\end{array}$ & $\begin{array}{l}0.047^{\star \star \star} \\
(0.017)\end{array}$ & & $\begin{array}{l}0.028^{\star *} \\
(0.014)\end{array}$ & $\begin{array}{l}0.029^{\star *} \\
(0.014)\end{array}$ & & & $\begin{array}{l}0.281^{\star \star \star} \\
(0.054)\end{array}$ \\
\hline Educational attainment & & $\begin{array}{l}0.186^{\star \star \star} \\
(0.048)\end{array}$ & $\begin{array}{l}0.186^{\star \star \star} \\
(0.048)\end{array}$ & & $\begin{array}{l}0.154^{\star \star \star} \\
(0.038)\end{array}$ & $\begin{array}{l}0.153^{\star \star \star} \\
(0.038)\end{array}$ & & & $\begin{array}{l}0.007 \\
(0.007)\end{array}$ \\
\hline Openness/Economic Freedom & & $\begin{array}{l}0.580^{\star \star *} \\
(0.197)\end{array}$ & $\begin{array}{l}0.560^{\star \star \star *} \\
(0.200)\end{array}$ & & $\begin{array}{l}0.278^{*} \\
(0.155)\end{array}$ & $\begin{array}{l}0.273^{*} \\
(0.155)\end{array}$ & & & $\begin{array}{l}0.004^{\star} \\
(0.003)\end{array}$ \\
\hline Money supply (\% of GDP) & & $\begin{array}{l}0.010^{\star \star \star} \\
(0.003)\end{array}$ & $\begin{array}{l}0.011^{\star \star \star} \\
(0.003)\end{array}$ & & $\begin{array}{l}0.011^{\star \star *} \\
(0.002)\end{array}$ & $\begin{array}{l}0.011^{\star \star \star} \\
(0.002)\end{array}$ & & & $\begin{array}{l}0.002^{\star \star \star} \\
(0.001)\end{array}$ \\
\hline Constant & & $\begin{array}{l}0.990 \\
(2.094)\end{array}$ & $\begin{array}{l}0.940 \\
(2.077)\end{array}$ & $\begin{array}{l}7.233^{\star * \star} \\
(0.898)\end{array}$ & $\begin{array}{l}3.872^{\star \star \star} \\
(1.351)\end{array}$ & $\begin{array}{l}3.819^{\star \star \star} \\
(1.343)\end{array}$ & $\begin{array}{l}8.158^{\star * *} \\
(0.211)\end{array}$ & $\begin{array}{l}5.544^{\star * *} \\
(0.413)\end{array}$ & $\begin{array}{l}5.533^{* \star \star} \\
(0.414)\end{array}$ \\
\hline No. of observations & 131 & 104 & 104 & 856 & 457 & 457 & 894 & 410 & 410 \\
\hline Adjusted $R^{2}$ & 0.472 & 0.595 & 0.600 & 0.406 & 0.524 & 0.524 & 0.515 & 0.769 & 0.771 \\
\hline Wald statistics & 39.752 & 48.09 & 40.79 & 93.91 & 39.18 & 34.45 & 28.48 & 32.69 & 30.99 \\
\hline
\end{tabular}

Note: Robust standard errors are in parentheses with robust standard errors. (ii) ${ }^{* * * * * * *}$ indicate significance level at the $1 \%, 5 \%$ and $10 \%$, respectively. 
Table 3. Average level of corruption and GDP per capita growth: East Asian Evidence

\begin{tabular}{llr}
\hline & CORR & GDPPCG \\
\hline China & 3.35 & 8.85 \\
\hline Hong Kong & 1.68 & 3.49 \\
\hline Mongolia & 3.06 & 2.94 \\
\hline South Korea & 2.92 & 5.36 \\
\hline
\end{tabular}

Note: CORR and GDPPCG denote corruption and GDP per capita growth

reported due to the limited space). The result suggests that if a country's GDP per capita in 1984 is higher than others, then the country's growth rate over the period is less than other countries. The interaction coefficient is negative and significant, which is consistent with our earlier results that the impact of corruption on growth reduces as a country's democracy level expands. ${ }^{11}$ Furthermore, the results suggest that corruption increases growth in East-Asian countries and this result is significant and positive in OLS, panel period FE and two-way FE.

\subsubsection{Two-stage least squares}

The TSLS estimates show that ET and lagged variables are good predictors of corruption and also confirm the panel least square and two-way FE estimates that joint effect of corruption and democracy is growth deterring, although the interaction term is not significant. The first stage estimation shows that ET coefficient is positive and significant at the $1 \%$ level indicating that corruption level increases significantly as ET increase in a country. This result is consistent with Mauro (1995). The first-stage $F$-value is 175.08 which is $>10$, suggesting that the instruments are not weak. ${ }^{12}$

System-GMM results are robust and provide a strong evidence that higher corruption does itself increase growth when countries are more autocratic (Appendix Table A4). The coefficients of the interaction terms are negative and significant for both ICRG and Polity measure of democracy, confirming our earlier results that corruption is growth-enhancing in autocracies (columns 1-4). The estimated coefficient for current per capita GDP growth with respect to its lagged value reveals a large degree of persistence in the level of GDP per capita growth. Other control variables such as higher investment, educational attainment and more open economy increase the rate of per capita income growth. On the other hand, a high inflation and population growth and a higher government final consumption level reduce economic growth. The model passes the test of absence of AR (2) in the error term and estimates are all robust. In both the cases, the model passes the Hansen- $J$ test. The results remain the same when the ICRG democracy index is replaced by Polity2 measure of institutionalized democracy indicator (columns 3-4).

\subsubsection{Transparency International's corruption perception index}

We extend the analysis by estimating the equations by using TI's CPI. The results for CPI measure in both cases (ICRG and Polity2 democracy measure) show that the estimated coefficients for the interaction term retain the same sign, although the level of significance varies. The evidence strongly supports the hypothesis that an increase in corruption increases the level of income per capita if the country becomes more autocratic. However, the results are not reported here due to limited space.

\subsection{Marginal effect of democracy and corruption}

This subsection provides a more rigorous analysis for the interaction effect between democracy and corruption on economic growth. The above findings show that a greater democracy does not foster

\footnotetext{
${ }^{11}$ The results are available upon request from the authors.

${ }^{12}$ The results are available upon request from the authors.
} 
growth in a more corrupt country. Oppositely, autocratic countries promote growth in the presence of corruption. In order to interpret the impact of democracy and corruption on per capita income growth, the marginal effects are estimated based on equations ( $2 a$ and $2 b$ ). Table 4 reports the results of the marginal effect of democracy and corruption on per capita income at various percentiles $\left(10^{\text {th }}, 25^{\text {th }}, 50^{\text {th }}, 75^{\text {th }}, 95^{\text {th }}\right.$ and mean $)$ of democracy and corruption using panel two-way FE.

For a deeper perspective, we provide the names of the countries to which these percentiles correspond in Table 4. The marginal effect of corruption on growth at the mean score of DEMO of 3.81 is 0.048. It suggests that a one standard deviation point increase in CORR increases income per capita by 0.05 points at the mean democracy index. As discussed earlier the impact of corruption shows some mixed results at different percentiles of democracy. If a country is less democratic then an increase in corruption is associated with greater economic growth; yet once past the threshold point (i.e. between $75^{\text {th }}$ and $95^{\text {th }}$ percentile), a higher level of corruption lowers growth as the economy becomes more democratic. ${ }^{13}$ Also, it is worth noting that the effect of corruption is significantly positive at the $10^{\text {th }}$ percentile when democratic freedom is very restricted (such as Togo) whereas, the effect is negative when the degree of political freedom is very high (above $95^{\text {th }}$ percentile). For example, Finland has a mature democracy (average score of 6 ) and is at the $95^{\text {th }}$ percentile in the sample and it experiences negative growth if there is an increase in corruption level. Conversely, the results show that lowering corruption has a significant positive impact on economic growth in democracies. In other words, if a country is highly democratic then the existence of a corrupt economy reduces growth. This suggests that an anti-corruption effort is a cure for growth if a country is highly democratic. Otherwise, a high level of corruption dampens growth in a democratic setting of a country like India. These empirical findings support the theoretical conjectures discussed in Section 2 of the paper.

On the other hand, the marginal effect of democracy on per capita income at the mean corruption score of 3.0 is 0.012 . This implies that a one standard deviation increase in democracy index increases growth by 0.02 points. The result indicates that the marginal effect of democracy has a positive impact on growth given an average level of corruption. In particular, democracy enhances growth significantly only when there exists a very low level of corruption (at the minimum score of corruption). For instance, Sweden has a very low corruption level (average corruption score is 0.0 ) and a one standard deviation rise in Sweden's democracy score, real per capita GDP increases by 4.31 points $\left(3.08^{\star} 1.40\right)$. However, the effect of democracy becomes negative when a country is very corrupt (for example Congo Democratic Republic). The result suggests that democracy is a cure for growth when a country is less corrupt.

The marginal effects are also estimated using System-GMM-Dynamic-Panel with GDP per capita growth as a dependent variable. The threshold level for the marginal effects of corruption and democracy are shown in Figures 4 and 5, respectively. The threshold level for the marginal effect of corruption is between 3 and 4 of democracy indices suggesting that after the threshold level of democracy, economic growth decreases as corruption level increases. The threshold level for the marginal effect of corruption is a little lower than the threshold level for the marginal effect of democracy (between 4 and 5). The results are very similar to two-way panel FE reported in Table 4.

\subsection{Results: autocratic countries}

This final step is to explore the channels that why and how corruption is growth-intensifying in autocratic countries. To answer this, the whole sample is divided into two groups based on the mean score of Polity2 democracy index and the countries with democracy value below the mean score are treated as autocratic. We re-run the estimations for the autocratic countries for the period 1984-2016 looking at our theoretical conjecture that credible commitments by the political leaders to the business can boost investment and in turn growth. The interaction effect of corruption and economic freedom

\footnotetext{
${ }^{13}$ Our results differ from Assiotis and Sylwester (2014) as the effect of corruption on growth is positive and significant in autocracy.
} 
Table 4. The effect of democracy and corruption on the growth of real GDP per capita: marginal effect analysis ${ }^{a}$

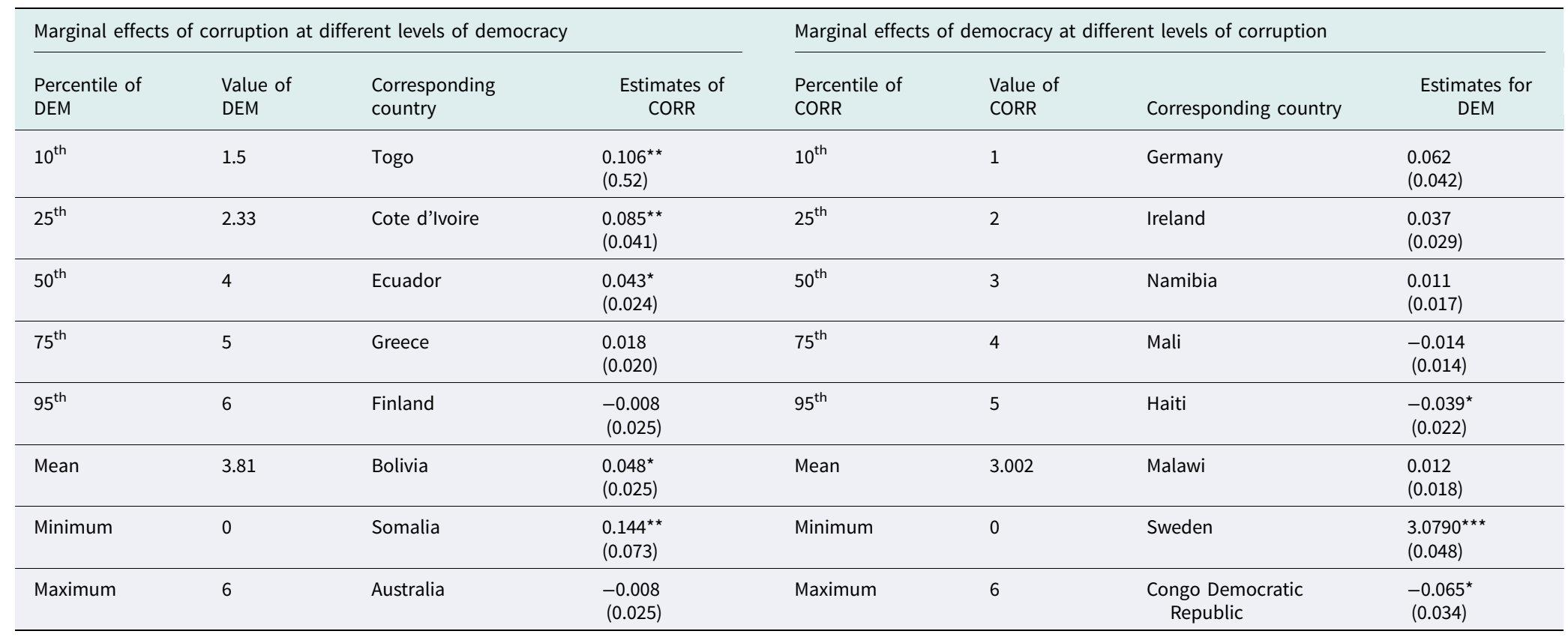

(i) Robust standard errors are in parentheses with robust standard errors. (ii) ${ }^{* * * * * * *}$ indicate significance level at the $1 \%, 5 \%$ and $10 \%$, respectively. (iii) CORR and DEM denote corruption and democracy (ICRG democracy Index), respectively.

${ }^{\mathrm{a}}$ Two-way fixed effects. 

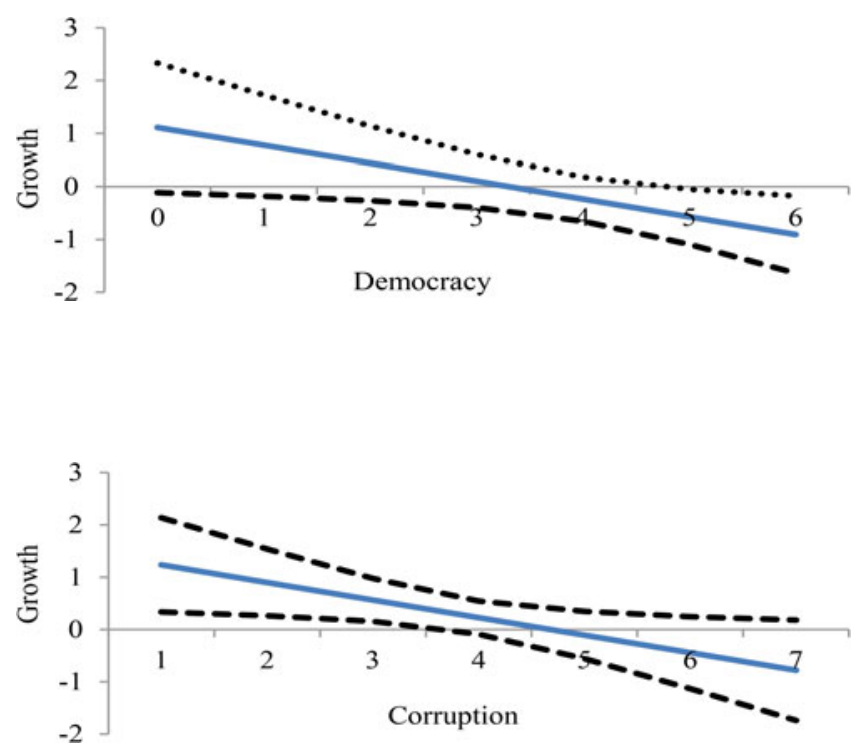

Figure 4. Marginal effect of corruption on growth.

Note: Higher values of the democracy measure indicate greater democracy.

Figure 5. Marginal effect of democracy on growth.

Note: Higher values of the corruption measure indicate higher corruption.

Table 5. Growth-corruption relationship in autocracies: 5-year average panel, 1984-2016

\begin{tabular}{|c|c|c|c|c|c|}
\hline & \multicolumn{5}{|c|}{ Fixed effects } \\
\hline & (1) & (2) & (3) & (4) & (5) \\
\hline Corruption & $\begin{array}{l}0.104^{\star \star} \\
(0.049)\end{array}$ & $\begin{array}{l}0.005 \\
(0.204)\end{array}$ & $\begin{array}{r}-0.019 \\
(0.251)\end{array}$ & $\begin{array}{l}0.935^{\star \star \star} \\
(0.344)\end{array}$ & $\begin{array}{l}0.206^{\star \star \star} \\
(0.080)\end{array}$ \\
\hline Corruption $\times$ Economic Freedom & & $\begin{array}{l}0.002 \\
(0.003)\end{array}$ & $\begin{array}{l}0.001 \\
(0.003)\end{array}$ & $\begin{array}{l}0.020^{\star \star \star} \\
(0.006)\end{array}$ & \\
\hline Corruption $\times$ Capital per capita & & & $\begin{array}{l}0.008 \\
(0.029)\end{array}$ & $\begin{array}{l}-0.114^{\star \star} \\
(0.050)\end{array}$ & \\
\hline $\begin{array}{l}\text { Corruption } \times \text { Capital per capita } \times \\
\text { Economic freedom }\end{array}$ & & & & $\begin{array}{l}0.003^{\star \star \star} \\
(0.001)\end{array}$ & \\
\hline Corruption $\times$ Money supply (\% of GDP) & & & & & $\begin{array}{c}-0.028^{*} \\
(0.016)\end{array}$ \\
\hline Capital per capita & $\begin{array}{l}0.389^{\star \star \star} \\
(0.104)\end{array}$ & $\begin{array}{l}0.383^{\star \star \star} \\
(0.103)\end{array}$ & $\begin{array}{l}0.343^{\star \star} \\
(0.146)\end{array}$ & $\begin{array}{l}0.290^{\star *} \\
(0.124)\end{array}$ & $\begin{array}{l}0.410^{\star \star \star} \\
(0.097)\end{array}$ \\
\hline Educational attainment & $\begin{array}{r}-0.010 \\
(0.026)\end{array}$ & $\begin{array}{r}-0.006 \\
(0.025)\end{array}$ & $\begin{array}{r}-0.009 \\
(0.025)\end{array}$ & $\begin{array}{l}-0.026 \\
(0.022)\end{array}$ & $\begin{array}{c}-0.008 \\
(0.025)\end{array}$ \\
\hline Economic freedom & $\begin{array}{l}0.009 \\
(0.007)\end{array}$ & $\begin{array}{l}0.004 \\
(0.010)\end{array}$ & $\begin{array}{l}0.006 \\
(0.011)\end{array}$ & $\begin{array}{l}0.0178 \\
(0.012)\end{array}$ & $\begin{array}{l}0.010 \\
(0.007)\end{array}$ \\
\hline Money supply (\% of GDP) & $\begin{array}{l}0.003^{\star \star \star} \\
(0.001)\end{array}$ & $\begin{array}{l}0.003^{\star \star \star} \\
(0.001)\end{array}$ & $\begin{array}{l}0.003^{\star \star \star} \\
(0.001)\end{array}$ & $\begin{array}{l}0.003^{\star \star} \\
(0.001)\end{array}$ & $\begin{array}{l}0.003^{\star \star \star} \\
(0.001)\end{array}$ \\
\hline Constant & $\begin{array}{l}4.444^{\star \star \star} \\
(0.744)\end{array}$ & $\begin{array}{l}4.754^{\star \star \star} \\
(0.763)\end{array}$ & $\begin{array}{l}4.939^{\star \star *} \\
(0.972)\end{array}$ & $\begin{array}{l}7.568^{\star \star \star} \\
(0.992)\end{array}$ & $\begin{array}{l}4.239^{\star \star \star} \\
(0.707)\end{array}$ \\
\hline No. of observations & 149 & 149 & 149 & 149 & 149 \\
\hline Adjusted $R^{2}$ & 0.741 & 0.742 & 0.741 & 0.793 & 0.748 \\
\hline Wald statistics & 13.09 & 11.99 & 10.82 & 12.73 & 13.79 \\
\hline
\end{tabular}

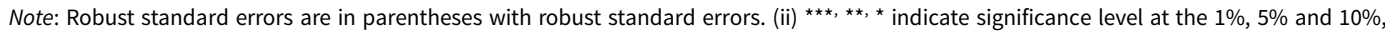
respectively. 
Table 6. Growth-corruption relationship in democracies: 5-year average panel, 1984-2016

\begin{tabular}{|c|c|c|c|c|c|}
\hline & \multicolumn{5}{|c|}{ Fixed effects } \\
\hline & (1) & (2) & (3) & (4) & (5) \\
\hline Corruption & $\begin{array}{l}0.002 \\
(0.016)\end{array}$ & $\begin{array}{l}-0.232^{\star \star} \\
(0.095)\end{array}$ & $\begin{array}{l}-0.334^{\star \star \star} \\
(0.126)\end{array}$ & $\begin{array}{l}0.051 \\
(0.308)\end{array}$ & $\begin{array}{l}-0.252^{\star \star \star} \\
(0.064)\end{array}$ \\
\hline Corruption $\times$ Economic Freedom & & $\begin{array}{l}0.004^{\star \star \star} \\
(0.001)\end{array}$ & $\begin{array}{l}0.003^{\star} \\
(0.001)\end{array}$ & $\begin{array}{r}-0.004 \\
(0.006)\end{array}$ & \\
\hline Corruption $\times$ Capital per capita & & & $\begin{array}{l}0.025^{\star} \\
(0.015)\end{array}$ & $\begin{array}{l}-0.0 .024 \\
(0.034)\end{array}$ & \\
\hline $\begin{array}{l}\text { Corruption } \times \text { Capital per capita } \times \\
\text { Economic freedom }\end{array}$ & & & & $\begin{array}{l}0.001 \\
(0.001)\end{array}$ & \\
\hline Corruption $\times$ Money supply ( $\%$ of GDP) & & & & & $\begin{array}{l}0.064^{\star \star \star} \\
(0.014)\end{array}$ \\
\hline Capital per capita & $\begin{array}{l}0.247^{\star \star \star} \\
(0.047)\end{array}$ & $\begin{array}{l}0.254^{\star \star \star} \\
(0.046)\end{array}$ & $\begin{array}{l}0.178^{\star \star \star} \\
(0.063)\end{array}$ & $\begin{array}{l}0.189^{\star \star} \\
(0.057)\end{array}$ & $\begin{array}{l}0.223^{\star \star \star} \\
(0.045)\end{array}$ \\
\hline Educational attainment & $\begin{array}{l}0.009 \\
(0.009)\end{array}$ & $\begin{array}{l}0.011 \\
(0.008)\end{array}$ & $\begin{array}{l}0.008 \\
(0.008)\end{array}$ & $\begin{array}{l}0.008 \\
(0.008)\end{array}$ & $\begin{array}{l}0.005 \\
(0.008)\end{array}$ \\
\hline Economic freedom & $\begin{array}{l}0.003 \\
(0.002)\end{array}$ & $\begin{array}{r}-0.009 \\
(0.006)\end{array}$ & $\begin{array}{r}-0.005 \\
(0.006)\end{array}$ & $\begin{array}{r}-0.004 \\
(0.001)\end{array}$ & $\begin{array}{l}0.003 \\
(0.002)\end{array}$ \\
\hline Money supply (\% of GDP) & $\begin{array}{l}0.001 \\
(0.001)\end{array}$ & $\begin{array}{l}0.001 \\
(0.001)\end{array}$ & $\begin{array}{l}0.001 \\
(0.001)\end{array}$ & $\begin{array}{l}0.001 \\
(0.001)\end{array}$ & $\begin{array}{r}-0.001 \\
(0.001)\end{array}$ \\
\hline Constant & $\begin{array}{l}7.966^{\star \star \star} \\
(0.224)\end{array}$ & $\begin{array}{l}7.441^{\star \star \star} \\
(0.422)\end{array}$ & $\begin{array}{l}7.778^{\star \star \star} \\
(0.494)\end{array}$ & $\begin{array}{l}7.580^{\star \star \star} \\
(0.462)\end{array}$ & $\begin{array}{l}7.054^{\star \star \star} \\
(0.333)\end{array}$ \\
\hline No. of observations & 251 & 251 & 251 & 251 & 251 \\
\hline Adjusted $R^{2}$ & 0.822 & 0.832 & 0.838 & 0.840 & 0.853 \\
\hline Wald statistics & 42.41 & 45.38 & 42.29 & 44.53 & 13.79 \\
\hline
\end{tabular}

Note: Robust standard errors are in parentheses with robust standard errors. (ii) ${ }^{* \star *} * \star * *$ indicate significance level at the $1 \%, 5 \%$ and $10 \%$, respectively.

on growth is estimated as Saha et al. (2009) and Faria et al. (2012) predict that economic freedom can enhance business activity by providing credibility to the investors. The results (Table 5) illustrate that coefficients on corruption are mostly positive and significant (columns 1,4-5) which is consistent with our earlier results. The interaction effect is positive revealing that corruption may grease the wheel if greater economic freedom is provided. Moreover, column 4 suggests that corruption with higher economic freedom increases growth if capital formation in a country is increased and the coefficient is highly significant. In other words, if political leaders in an autocratic country deliver credibility by providing freedom to run business even at the cost of sharing rents, this leads to higher investment and growth in that country. The result is consistent with Mullings (2018) which finds a direct effect of economic globalization on growth observed for the sub-sample of developing countries. The results for the subsample of democratic countries reveal that economic freedom is not efficient in controlling corruption and increasing growth for these countries (Table 6). The result is consistent with Saha et al. (2009), which find that economic freedom is needed more to combat corruption than political freedom. The case of India supports this finding as India, while being the largest democracy in the world, has less economic freedom than China and South Korea.

For the robustness check, we have also selected the whole sample into autocracies $(-10$ to -6$)$ and democracies $(+6$ to +10$)$ based on the Center for Systemic Peace (CSP). These results confirm our earlier results presented in Tables 5 and 6 . However, the number of observations for the autocracies is very low (only 33). We have also organized the subsamples using general consensus that ( -10 to 0$)$ for 
autocracies and $(1$ to +10$)$ for democracies and the results are robust and consistent with all three measures of autocracies and democracies defined in this study. ${ }^{14}$

On the other channel, if a greater money supply is dechannelized from the economy due to a higher level of corruption, this can have a negative effect on growth by disturbing macroeconomic stability in autocratic countries. The coefficient for the interaction term between corruption and money supply is negative and significant (column 5, Table 4) indicating that if autocracies (with greater monopolization of power) suffer from corrupt activities by political elites, this can lead to less resources resulting in negative growth and lower investment. The results explain that not all autocracies are growth-enhancing with the presence of corruption.

\section{Conclusions}

A large literature has examined the effect of corruption on growth. In this paper, we examine whether the corruption-growth relationship is likely to be different in autocracies as compared to democracies. We use a panel data set of over 100 countries, for the period 1984-2016. We estimate the relationship between corruption and growth using various panel estimation techniques including FE, TSLS and Dynamic-Panel-System-GMM methods. We also use different measures of democracy and corruption. Our results are remarkably consistent. We find that on average, the effect of corruption on growth is positive in autocracies as compared to democracies.

Our results provide support for the so-called East Asian paradox of high corruption and high growth and suggest that the benign effect of corruption on growth is because of the authoritarian nature of the political regimes in these countries for a large duration of their development experience. The political regimes in these countries gave firms confidence that the ruling powers will deliver on the deals that they have entered into. We present suggestive evidence that the key mechanism was the credible commitment of political leaders in East Asia to economic freedom and maintaining a probusiness environment, albeit with crony capitalist arrangements. On the contrary, for the average democratic countries, the effect of corruption on growth is likely to be strongly negative. Democratization is likely to weaken the positive relationship between corruption and growth in previously autocratic countries, and the increasing wave of democratization observed in the developing world suggests that corruption may be more of a threat to economic growth in the years ahead.

\section{References}

Acemoglu, D., S. Naidu, P. Restrepo and J. A. Robinson (2014), 'Democracy Does Cause Growth', MIT, Department of Economics. Working paper 14-09, Cambridge, MA.

Aidt, T., J. Dutta and V. Sena (2008), 'Governance Regimes, Corruption and Growth: Theory and Evidence', Journal of Comparative Economics, 36(2): 195-220.

Alfonso-Gil, J., M. Lacalle-Calderón and R. Sánchez-Mangas (2014), 'Civil Liberty and Economic Growth in The World: A Long-Run Perspective, 1850-2010', Journal of Institutional Economics, 10(3): 427-449.

Ang, Y. Y. (2019), 'Unbundling Corruption: Revisiting Six Questions on Corruption', Global Perspectives, 1(1): 1-19.

Ang, Y. Y. (2020), China's Gilded Age: The Paradox of Economic Growth and Vast Corruption, Cambridge: Cambridge University Press.

Assiotis, A. and K. Sylwester (2014), 'Do the Effects of Corruption Upon Growth Differ Between Democracies and Autocracies? Democracy-Autocracy Corruption Effects', Review of Development Economics, 18(3): 581-594.

Baltagi, B. H. (2008), Econometric Analysis of Panel Data, West Sussex: Wiley.

Bardhan, P. (1984), The Political Economy of Development in India, Oxford: Basil Blackwell.

Bardhan, P. (1997), 'Corruption and Development: A Review of Issues', Journal of Economic Literature, 35(3): 1320-1346. Barro, R. J. (1991), 'Economic Growth in a Cross Section of Countries', Quarterly Journal of Economics, 106(2): 407-443. Barro, R. J. (1996), 'Democracy and Growth', Journal of Economic Growth, 1(March 1996): 1-27.

Basu P., K. Bhattarai and Y. Gatechew (2019), 'Capital Adjustment Cost and Inconsistency in Income Based Dynamic Panel Models with Fixed Effects', German Economic Review, 20(4). https://doi.org/10.1111/geer.12202.

\footnotetext{
${ }^{14}$ The results are available upon request from the authors.
} 
Bates, R. (1981), Markets and States in Tropical Africa: The Political Basis of Agricultural Policies, Berkeley: University of California Press.

Benyishay, A. and R. R. Betancourt (2010), 'Civil Liberties and Economic Development', Journal of Institutional Economics, 6 (3): 281-304.

Berggren, N., A. Bergh and A. Bjørnskov (2012), 'The Growth Effects of Institutional Instability', Journal of Institutional Economics, 8(2): 187-224.

Bhagwati, J. (1993), India in Transition, Oxford: Oxford University Press.

Blundell, R. and S. Bond (1998), 'Initial Conditions and Moment Restrictions in Dynamic Panel Data Models', Journal of Econometrics, 87(1): 115-143

Bond, S. R., A. Hoeffler and J. Temple (2001), 'GMM Estimation of Empirical Growth Models'. CEPR Discussion Papers 3048.

Bratton, M and E. Masunungure (2011), 'The Anatomy of Political Predation: Leaders, Elites and Coalitions in Zimbabwe, 1980-2010', Development Leadership Program, University of York, Paper No. 9.

Bratton, M. and N. Van de Walle (1994), 'Neopatrimonial Regimes and Political Transitions in Africa', World Politics 46 (4): 453-489.

Campos, J. E. (2002), Corruption: The Boom and Bust of East Asia, Manila: Ateneo de Manila Press.

Campos, N. F. and F. Giovannoni (2017), 'Political Institutions, Lobbying and Corruption', Journal of Institutional Economics, 13(4): 917-939.

Coolidge, J and S. Rose-Ackerman (1999), 'High Level Rent Seeking and Corruption in African Regimes: Theory and Cases', World Bank Policy Research Working Paper.

Cooray, A., N. Dutta and S. Mallick (2017), 'The Right To Be Free: Is Media Freedom Good News For Women's Rights?', Journal of Institutional Economics, 13(2): 327-355.

Coppedge, M. (2002), 'Democracy and Dimensions: Comments on Munck and Verkuilen', Comparative Political Studies, 35 (1): 35-39.

Dal Bó, E. and M. A. Rossi (2007), 'Corruption and Inefficiency: Theory and Evidence from Electric Utilities', Journal of Public Economics, 91(5-6): 939-962.

De Soto, H. (1989), The Other Path: The Invisible Revolution in the Third World, New York: Harper and Row.

Egger, P. and H. Winner (2005), 'Evidence on Corruption as an Incentive for Foreign Direct investment', European Journal of Political Economy, 21(4): 932-952.

Ehrlich, I. and F. T. Lui (1999), 'Bureaucratic Corruption and Endogenous Economic Growth', Journal of Political Economy, 107(S6): S270-S293.

Faria, H. J., D. R. Morales, N. Pineda and H. M. Montesinos (2012), 'Can Capitalism Restrain Public Perceived Corruption? Some Evidence', Journal of Institutional Economics, 8(4): 511-535.

Fisman, R and J. Svensson (2001), 'Are Corruption and Taxation Really Harmful to Growth? Firm Level Evidence'. Manuscript, IIES, Stockholm University.

Gill, I. and H. Kharas (2007), An East Asian Renaissance: Ideas For Economic Growth, Washington, DC: World Bank.

Greif, A. and J. Mokyr (2017), 'Cognitive Rules, Institutions, and Economic Growth: Douglass North and Beyond', Journal of Institutional Economics, 13(1): 25-52.

Haber, S. (ed.) (2002), Crony Capitalism and Growth in Latin America: Theory and Evidence, Stanford, CA: Hoover Institution Press.

Huntington, S. P. (1968), Political Order in Changing Societies, New Haven: Yale University Press.

Jalles, J. T. (2010), 'Does Democracy Foster or Hinder Growth? Extreme-type Political Regimes in a Large Panel', Economics Bulletin, 30(2): 1359-1372.

Kang, D. (2002a), 'Bad Loans to Good Friends: Money Politics and the Developmental State in South Korea', International Organization, 56(1): 177-207.

Kang, D. (2002b), Crony Capitalism: Corruption and Development in South Korea and the Philippines, Cambridge: Cambridge University Press.

Kar, S. and K. Sen (2016), The Political Economy of India's Growth Episodes, London: Palgrave Macmillan.

Keefer, P. and S. Knack (1997), 'Why Don't Poor Countries Catch Up? A Cross-national Test of an Institutional Explanation', Economic Inquiry, 35(3): 590-602.

Khan, M. H. (1996), 'The Efficiency Implications of Corruption', Journal of International Development, 8(5): 683-696.

Khan, M. (2006). 'Corruption and Governance', in S. K. Jomo and F. Ben (eds.), The New Development Economics: After the Washington Consensus, London and New Dehli: Zed Press and Tulika, pp. 200-221.

Khan, M. and K. S. Jomo (2000), Rents, Rent-Seeking and Economic Development: Theory and Evidence from Asia, Cambridge: Cambridge University Press.

Kochanek, S. (1996), 'Liberalisation and Business Lobbying in India', Journal of Commonwealth and Comparative Politics, 34 (3): 155-193.

Krueger, A. O. (1974), 'The Political Economy of the Rent-Seeking Society', American Economic Review, 64(3): 291-303.

Leff, N. H. (1964), 'Economic Development Through Bureaucratic Corruption', American Behavioral Scientist, 8(3): 8-14. 
Lui, F. T. (1985), 'An Equilibrium Queuing Model of Bribery', Journal of Political Economy, 93(4): 760-781.

Mandaza, I. (ed.) (1986), Zimbabwe: The Political Economy of Transition, 1980-1986, Dakar: CODESRIA.

Mankiw, N. G., D. Romer and D. N. Weil (1992), 'A Contribution to the Empirics of Growth', Quarterly Journal of Economics, 107(2): 407-437.

Mauro, P. (1995), 'Corruption and growth', Quarterly Journal of Economics, 110(3): 681-712.

Mauro, P. (1997), 'The Effects of Corruption on Growth, Investment, and Government Expenditure: A Cross Country Analysis', in K. Ann Elliott (ed), Corruption and The Global Economy, Washington: Institute for International Economics, pp. 83-107.

Méndez, F. and F. Sepúlveda (2006), 'Corruption, Growth and Political Regimes: Cross Country Evidence', European Journal of Political Economy, 22(1): 82-98.

Méon, P.-G. and K. Sekkat (2005), 'Does Corruption Grease or Sand the Wheels of Growth?', Public Choice, 122: 69-97.

Mo, P. H. (2001), 'Corruption and Economic Growth', Journal of Comparative Economics, 29(1): 66-79.

Mullings, R. (2018), 'Do Institutions Moderate Globalization's Effect on Growth?', Journal of Institutional Economics, 14(1): 71-102.

Munck, G. L. and J. Verkuilen (2002), 'Conceptualizing and Measuring Democracy', Comparative Political Studies, 35(1): 534.

Ndulu, B. and S. O’Connell (1999), 'Governance and Growth in Sub-Saharan Africa', Journal of Economic Perspectives, 13(3): 41-66.

Olson, M. (1993), 'Dictatorship, Democracy and Development', American Political Science Review, 87(3): 567-576.

Papaioannou, E. and G. Siourounis (2008), 'Democratisation and Growth', The Economic Journal, 118(532): $1520-1551$.

Pellegrini, L. and L. Gerlagh (2004), 'Corruption's Effect on Growth and its Transmission Channels', KYKLOS, 57(3): 429456.

Persson, T. and G. Tabellini (2007), 'The Growth Effect of Democracy: is it Heterogenous and How Can it be Estimated?' CESifo Working Paper Series 2016, CESifo Group Munich.

Pritchett, L. and E. Werker (2013), 'Developing the Guts of GUT (Grand Unified Theory): Elite Commitment and Inclusive Growth', ESID Working Paper No. 16/12.

Rajan, R. G. and A. Subramanian (2008), 'Aid and Growth: What Does The Cross-Country Evidence Really Show?', The Review of Economics and Statistics, 90(4): 643-665.

Reinikka, R. and J. Svensson (2005), 'Fighting Corruption to Improve Schooling: Evidence From a Newspaper Campaign in Uganda', Journal of the European Economic Association, 3(2-3): 259-267.

Rock, M. T. and H. Bonnett (2004), 'The Comparative Politics of Corruption: Accounting for the East Asian Paradox in Empirical Studies of Corruption, Growth and Investment', World Development, 32(6): 999-1017.

Rodrik, D. and R. Wacziarg (2005), 'Do Democratic Transitions Produce Bad Economic Outcomes?' American Economic Review, 95(2): 50-55.

Romer, P. M. (1990), 'Endogenous Technological Change’, Journal of Political Economy, 98(5): S71-S102.

Rose-Ackerman, S. (1978), Corruption: A Study of Political Economy, New York: Academic Press.

Saha, S. and R. Gounder (2013), 'Corruption and Economic Development Nexus: Variations Across Income Levels in a Non-linear Framework', Economic Modelling, 31(March 2013) 70-79.

Saha, S., R. Gounder and J. Su (2009), 'The Interaction Effect of Economic Freedom and Democracy on Corruption: A Panel Cross-Country Analysis', Economics Letters, 105(2): 173-176.

Saha, S., R. Gounder, N. Campbell and J. J. Su (2014), 'Democracy and Corruption: A Complex Relationship', Crime Law and Social Change, 61(January 2014): 287-308.

Sen, K. (2013), 'The Political Dynamics of Economic Growth', World Development, 47(July 2013): 71-86.

Shleifer, A. and R. W. Vishny (1993), 'Corruption', Quarterly Journal of Economics, 108(3): 599-617.

Solow, R. M. (1956), 'A Contribution to the Theory of Economic Growth', The Quarterly Journal of Economics, 70(1): 65-94.

Swaleheen, M. (2011), 'Economic Growth with Endogenous Corruption: An Empirical Study', Public Choice, 146: $23-41$.

Tanzi, V and H. Davoodi (1997), 'Corruption, Public Investment, and Growth', International Monetary Fund Working Paper: WP/97/139.

Tavares, J. and R. Wacziarg (2001), 'How Democracy Affects Growth', European Economic Review, 45(8): $1341-1378$.

Cite this article: Saha S, Sen K (2021). The corruption-growth relationship: does the political regime matter? Journal of Institutional Economics 17, 243-266. https://doi.org/10.1017/S1744137420000375 
Table A1. Descriptive statistics (5-year average panel)

\begin{tabular}{lcccccccrrr}
\hline & GDPPC & CORR & DEM & DEMP & EDU & CAPPC & OPEN & EF & RND & M2GDP \\
\hline Mean & $13,491.30$ & 3.057 & 3.817 & 14.241 & 9.199 & $3,457.210$ & 80.907 & 60.886 & 0.917 & 52.433 \\
\hline Median & $4,910.661$ & 3.267 & 4.000 & 17.000 & 9.000 & $1,439.777$ & 69.192 & 61.100 & 0.571 & 40.981 \\
\hline Maximum & $106,791.1$ & 6.000 & 6.000 & 21.000 & 16.000 & $24,312.39$ & 419.974 & 89.720 & 4.244 & 366.916 \\
\hline Minimum & 143.4264 & 0.000 & 0.000 & 1.000 & 4.000 & $-2,881.580$ & 0.250 & 16.800 & 0.007 & 3.090 \\
\hline Std. Dev. & $18,096.42$ & 1.286 & 1.599 & 6.666 & 2.164 & $4,414.655$ & 53.401 & 10.925 & 0.921 & 41.426 \\
\hline Observations & 913 & 919 & 920 & 900 & 629 & 754 & 881 & 639 & 467 & 766 \\
\hline
\end{tabular}


Table A2. Data source

\begin{tabular}{|c|c|}
\hline Variables & Data source \\
\hline Corruption & $\begin{array}{l}\text { Source from International Country Risk Guide (ICRG). The ICRG index is } \\
\text { constructed by Political Risk Services. } \\
\text { http://www.prsgroup.com/countrydata.aspx. }\end{array}$ \\
\hline Corruption perceptions index & $\begin{array}{l}\text { Transparency International } \\
\text { http://www.transparency.org/policy_research/surveys_indices/cpi }\end{array}$ \\
\hline Democracy & $\begin{array}{l}\text { Source from International Country Risk Guide (ICRG). The ICRG index is } \\
\text { constructed by Political Risk Services. } \\
\text { http://www.prsgroup.com/countrydata.aspx }\end{array}$ \\
\hline $\begin{array}{l}\text { Polity2 institutionalized democracy } \\
\text { index }\end{array}$ & $\begin{array}{l}\text { Source from Polity IV Data Set } \\
\text { http://www3.nd.edu/ mcoppedg/crd/PolityIVUsersManualv2002.pdf. }\end{array}$ \\
\hline $\begin{array}{l}\text { Real GDP per capita (constant } 2010 \\
\text { US\$) }\end{array}$ & $\begin{array}{l}\text { World Bank (2017) World Development Indicators. } \\
\text { http://data.worldbank.org/data-catalog/world-development-indicators }\end{array}$ \\
\hline $\begin{array}{l}\text { Gross capital formation } \\
\text { (constant } 2010 \text { US\$) }\end{array}$ & $\begin{array}{l}\text { World Bank (2017) World Development Indicators. } \\
\text { http://data.worldbank.org/data-catalog/world-development-indicators }\end{array}$ \\
\hline Population & $\begin{array}{l}\text { World Bank (2017) World Development Indicators. } \\
\text { http://data.worldbank.org/data-catalog/world-development-indicators }\end{array}$ \\
\hline Openness (constant 2010 US\$) (\%) & $\begin{array}{l}\text { World Bank (2017) World Development Indicators. } \\
\text { http://data.worldbank.org/data-catalog/world-development-indicators }\end{array}$ \\
\hline Economic freedom & $\begin{array}{l}\text { The Heritage Foundation } \\
\text { https://www.heritage.org/index/ }\end{array}$ \\
\hline Educational attainment & $\begin{array}{l}\text { World Bank (2017) World Development Indicators. } \\
\text { http://data.worldbank.org/data-catalog/world-development-indicators }\end{array}$ \\
\hline $\begin{array}{l}\text { Research and development } \\
\text { expenditure (\% of GDP) }\end{array}$ & $\begin{array}{l}\text { World Bank (2017) World Development Indicators } \\
\text { http://data.worldbank.org/data-catalog/world-development-indicators }\end{array}$ \\
\hline Ethnic tensions & $\begin{array}{l}\text { Source from International Country Risk Guide (ICRG). The ICRG index is } \\
\text { constructed by Political Risk Services. } \\
\text { http://www.prsgroup.com/countrydata.aspx. }\end{array}$ \\
\hline
\end{tabular}

Table A3. Correlation coefficient: 5-year panel data

\begin{tabular}{lccccccc}
\hline & CORR $\times$ DEM & CORR & DEM & GDPPC & GDPPG & LGDPPC & ET \\
\hline CORR $\times$ DEM & 1.000 & 0.551 & 0.354 & -0.331 & 0.090 & -0.183 & 0.123 \\
\hline CORR & 0.551 & 1.000 & -0.530 & -0.629 & 0.022 & -0.582 & 0.341 \\
\hline DEM & 0.354 & -0.530 & 1.000 & 0.450 & 0.078 & 0.507 & -0.239 \\
\hline GDPPC & -0.331 & -0.629 & 0.450 & 1.000 & -0.059 & 0.825 & -0.335 \\
\hline GDPPCG & 0.090 & 0.022 & 0.078 & -0.059 & 1.000 & 0.006 & -0.072 \\
\hline LGDPPC & -0.183 & -0.582 & 0.507 & 0.825 & 0.006 & 1.000 & -0.441 \\
\hline ET & 0.123 & 0.341 & -0.239 & -0.335 & -0.072 & -0.441 & 1.000 \\
\hline
\end{tabular}

Note: CORR is corruption, DEM is democracy, GDPPC is GDP per capita, GDPPCG is GDP per capita growth, LGDPPC is log GDP per capita and $E T$ is ethnic tension. 
Table A4. Corruption, democracy and growth using System-GMM: 1984-2016

\begin{tabular}{|c|c|c|c|c|}
\hline $\begin{array}{l}\text { Dependent variable - } \\
\text { annual growth rate of real } \\
\text { GDP per capita }\end{array}$ & $\begin{array}{l}\text { ICRG } \\
\text { democracy } \\
\text { index } \\
\text { (1) }\end{array}$ & $\begin{array}{c}\text { ICRG } \\
\text { democracy } \\
\text { index } \\
(2)\end{array}$ & $\begin{array}{l}\text { Polity2 measure } \\
\text { of democracy } \\
\text { index } \\
\text { (3) }\end{array}$ & $\begin{array}{c}\text { Polity2 measure } \\
\text { of democracy } \\
\text { index } \\
\text { (4) }\end{array}$ \\
\hline $\begin{array}{l}\text { Lagged real GDP per capita } \\
\text { growth }\end{array}$ & $\begin{array}{l}0.2082^{\star \star} \\
(2.33)\end{array}$ & $\begin{array}{l}0.1801^{\star *} \\
(1.97)\end{array}$ & $\begin{array}{l}0.5624^{*} \\
(1.64)\end{array}$ & $\begin{array}{l}0.3598^{\star \star \star} \\
(3.23)\end{array}$ \\
\hline Corruption & $\begin{array}{l}2.0519 \\
(1.48)\end{array}$ & $\begin{array}{l}3.4074^{\star \star} \\
(2.00)\end{array}$ & $\begin{array}{l}0.9881 \\
(1.12)\end{array}$ & $\begin{array}{l}2.5785^{\star} \\
(1.93)\end{array}$ \\
\hline Democracy & $\begin{array}{l}2.3899^{\star *} \\
(2.46)\end{array}$ & $\begin{array}{l}3.0790^{* * *} \\
(2.61)\end{array}$ & $\begin{array}{l}0.2793 \\
(1.56)\end{array}$ & $\begin{array}{l}0.7059^{\star *} \\
(2.44)\end{array}$ \\
\hline Corruption $\times$ Democracy & $\begin{array}{l}-0.5535^{\star} \\
(1.79)\end{array}$ & $\begin{array}{l}-0.7190^{\star \star} \\
(1.99)\end{array}$ & $\begin{array}{l}-0.0910^{\star} \\
(1.84)\end{array}$ & $\begin{array}{l}-0.1633^{\star \star} \\
(1.95)\end{array}$ \\
\hline Educational attainment & & $\begin{array}{l}0.0133 \\
(0.39)\end{array}$ & & $\begin{array}{l}0.0124 \\
(0.27)\end{array}$ \\
\hline Govt. exp. (\% of GDP) & & $\begin{array}{l}-1.4668 \\
(1.49)\end{array}$ & & $\begin{array}{l}-2.1579 \\
(0.94)\end{array}$ \\
\hline $\begin{array}{l}\text { Openness/Economic } \\
\text { freedom }\end{array}$ & & $\begin{array}{l}1.0570 \\
(0.42)\end{array}$ & & $\begin{array}{l}2.2746 \\
(1.05)\end{array}$ \\
\hline Population growth & & $\begin{array}{l}-0.3926 \\
(0.76)\end{array}$ & & $\begin{array}{l}0.9463 \\
(0.94)\end{array}$ \\
\hline Capital per capita & & $\begin{array}{l}0.1050 \\
(1.09)\end{array}$ & & $\begin{array}{l}-0.0188 \\
(0.22)\end{array}$ \\
\hline Inflation & & $\begin{array}{l}-0.2948 \\
(0.56)\end{array}$ & & $\begin{array}{l}0.0654 \\
(0.32)\end{array}$ \\
\hline Constant & $\begin{array}{l}-8.5705^{\star} \\
(1.84)\end{array}$ & $\begin{array}{l}-22.1940 \\
(1.60)\end{array}$ & & $\begin{array}{l}-22.5699 \\
(1.64)\end{array}$ \\
\hline $\begin{array}{l}\text { Autocorrell (1) } p \text {-values } \\
\text { Autocorrell (2) }\end{array}$ & $\begin{array}{l}(0.020) \\
(0.436)\end{array}$ & $\begin{array}{l}(0.021) \\
(0.636)\end{array}$ & $\begin{array}{l}(0.058) \\
(0.841)\end{array}$ & $\begin{array}{l}(0.001) \\
(0.875)\end{array}$ \\
\hline $\begin{array}{l}\text { Hansen } J \text {-statistic } \\
\quad(p \text {-value })\end{array}$ & $\begin{array}{l}\text { (0.119) } \\
\text { Robust }\end{array}$ & $\begin{array}{l}\text { (0.181) } \\
\text { Robust }\end{array}$ & $\begin{array}{l}0.230 \\
\text { Robust }\end{array}$ & $\begin{array}{l}\text { (0.447) } \\
\text { Robust }\end{array}$ \\
\hline $\begin{array}{c}\text { Wald Statistic } \\
\quad(p \text {-value })\end{array}$ & $(0.000)$ & $(0.000)$ & $(0.000)$ & $(0.000)$ \\
\hline No. of countries & 136 & 134 & 104 & 103 \\
\hline No. of observations & 3,579 & 3,517 & 2,667 & 2,636 \\
\hline
\end{tabular}

Notes: (i) $t$-statistics are in parentheses with robust standard errors. (ii) ${ }^{* \star *}, * *, *$ indicate significance level at the $1 \%, 5 \%$ and $10 \%$, respectively. (iii) Annual panel data are used to avoid less number of observations due to various lag instruments used in the estimation. 